\title{
1 Identification and Characterization of a Buried Volcanic Field Using \\ 2 Seismic Reflection and Borehole Data
}

3 Alan Bischoff ${ }^{a *}$, Marcos Rossetti, Andrew Nicol and Ben Kennedy

$4 \quad{ }^{a}$ Department of Geological Sciences, University of Canterbury, Christchurch, New

5 Zealand;

6 alan.bischoff@,canterbury.ac.nz * corresponding author $\backslash$

This is a non-peer reviewed preprint submitted to EarthArXiv.

9 It has been submitted on February 13, 2019 to Bulletin of Volcanology.

\section{Abstract}

11 Buried volcanoes occur in great numbers within sedimentary basins globally.

12 Knowledge of ancient buried volcanic systems has improved significantly over the past

13 two decades. The in-depth understanding of these buried systems was mainly possible

14 due to increasing availability of high-quality seismic reflection and sub-surface

15 borehole data. This paper examines a cluster of Miocene volcanoes now buried by ca

$161000 \mathrm{~m}$ of sedimentary strata in the Canterbury Basin, New Zealand. These volcanoes

17 were imaged by 2D seismic lines and perforated by the Resolution-1 borehole. We refer

18 to this group of volcanoes and related intrusive bodies as the Maahunui Volcanic Field

19 (MVF). Here, we present detailed petrographic and seismic reflection interpretation of

20 some representative volcanoes of the MVF, and of the strata that enclose them, to

21 constrain the environments in which intrusions and eruptions occurred. Intrusive rocks

22 penetrated by the Resolution-1 comprise a monzogabbro body with a saucer-shape

23 geometry emplaced in organic-rich sedimentary layers. The monzogabbro contains

24 miarolitic cavities and ophitic textures which, together with decompaction of its

25 overburdened sedimentary strata, suggest an emplacement depth around $950 \mathrm{~m}$ below 
the paleo-seafloor. Seismic lines show an array of faults at the tips of the saucer-shaped monzogabbro. These faults are connected with the root of some volcanoes, and may have formed feeder systems for eruptions and hydrothermal fluids onto the Miocene paleo-seafloor. Volcaniclastic rocks comprise abundant glassy shards, relics of bubble walls, spheroidal fragments enveloped in a palagonite film, broken phenocrysts, and

31 lithics. These volcaniclastic rocks are interbedded with lower bathyal siltstones,

32 indicating that eruptions near the location of the Resolution-1 occurred in a deepsubmarine environment (1000-1500 m). Integration of petrographic, geochemical and seismic reflection interpretations suggest that the volcaniclastic rocks have a genetic relationship with the saucer-shaped monzogabbro, which may have served as a shallow stationary magma chamber for some volcanoes in the MVF. The available data indicate processes of intense material fragmentation and particle dispersion, consistent with phreatomagmatic eruptions, although globally this eruptive style is rarely interpreted to occur at water depths around $1000 \mathrm{~m}$. The emplacement of intrusions into organic-rich sedimentary rocks could incorporate thermogenic gases into the magmatic system,

41 providing supplementary driving forces to form large deep-water pyroclastic eruptions.

43 Keywords: buried volcanoes; seismic reflection; deep-water eruptions.

\section{Introduction}

Buried volcanoes are common in sedimentary basins globally (e.g. Field et al. 1989; Holford et al. 2012; Giba et al. 2013; Planke et al. 2017). These "fossil"

47 volcanoes are the remains of ancient volcanic systems that erupted onto the Earth's surface in the past, which are now buried and preserved within sedimentary strata in the subsurface. Advances in seismic interpretation techniques together with an increasing availability of high-quality seismic data have helped to significantly improve our 
understanding of volcanoes preserved in sedimentary basins. Characterization of buried volcanoes is often best achieved by integrating large datasets of 2D and 3D seismic surveys, along with biostratigraphic, geochronological, geochemical, petrophysical and petrographic information from boreholes (e.g. Planke et al. 1999; Single and Jerram 2004; Schofield et al. 2016; McLean et al. 2017). Interpretation of these datasets as part of a multidisciplinary approach that correlates insights from disciplines such as stratigraphy, sedimentology and volcanology can produce unified models to explain the genesis and evolution of buried volcanic systems (e.g. Herzer 1995; Planke et al. 2000; Bischoff 2019). Information from these complementary datasets provide improved knowledge of the main geological processes that create, transform, and preserve volcanoes now buried in sedimentary basins (e.g. Huafeng et al. 2015; Reynolds et al. 2016; Bischoff et al. 2017; Infante-Paez and Marfurt 2017).

The present work studies part of a cluster of middle Miocene volcanoes currently buried by ca 1000 m of sedimentary strata in the offshore Canterbury Basin, east of New Zealand's South Island (Figure 1). We refer to these volcanoes as the Maahunui Volcanic Field (MVF), from the Māori name for the stretch of coast south of Banks Peninsula (aka Canterbury Bight) and immediately adjacent to the study area. Volcanic activity of Miocene age was previously identified in the study area by $2 \mathrm{D}$ seismic reflection surveys, and by intrusive and extrusive rocks sampled in the Resolution-1 petroleum exploration well (Milne 1975; Field et al. 1989). Despite an initial effort to recognize these buried volcanoes, important information on their origin and evolution was missing prior to the present study.

The geological history of the MVF is presented in three inter-related papers, although each one can be read and understood separately. This is the first paper and focuses on seismic reflection analysis in the vicinity of the well Resolution-1, and on 
the petrographic characterization of the igneous rocks and enclosing sedimentary strata sampled in this well. The second paper (Bischoff et al. 2019a) is designed to present the results of the seismic morphological and paleogeographic reconstruction of the MVF area, in which we up-scale interpretations from the location of the Resolution-1 to a regional scale. In the third paper (Bischoff et al. 2019b), we unravel the complete architecture of the MVF from emplacement to burial, characterizing its main intrusive, eruptive, and sedimentary architectural elements, and their impact on geoenergy resources such as hydrocarbons and geothermal energy. The knowledge of the "fossil" volcanoes of MVF can provide useful insights of how volcanic fields form and evolve elsewhere, including their perceived geological hazards, and potential to contain socioeconomical resources.

\section{Geological Setting}

Sedimentation in the northern Canterbury Basin began in the late Cretaceous, after the initial stages of the separation of Zealandia from eastern Gondwana and opening of the Tasman Sea. In the study area, paralic to shallow marine conditions

91 prevail until the early Eocene, with deposition of sandstones, mudstones and coal beds of the Broken River and Conway Formation, and Charteris Bay Sandstone. Continuous marine transgression throughout the late Paleogene favour the formation of shallow-to deep-water sediments of the Ashley Mudstone and Amuri Limestone. In the early Neogene, the present oblique-convergent boundary between the Pacific and Australian

96 plates induced uplift and erosion of the western part of the Canterbury Basin, with

97 progradation of marine to continental sediments of the Tokama and Kowai Formation towards the southeast (e.g. Suggate et al. 1978; Field et al. 1989; Kamp et al. 1992; Mortimer et al. 2004; Strogen et al. 2017; Barrier 2019; Figure 2 and 3). 
Igneous rocks often pierce and interbed with strata of the northern Canterbury

101 Basin sedimentary succession. Onshore, the most expressive products of volcanism is represented by the Mount Sommers Volcanic Group (Cretaceous), View Hill Volcanics

103 (Eocene), and Miocene igneous rocks of the Burnt Hills Group and Banks Peninsula

104 (e.g. Carlson et al. 1980; Field et al. 1989; Forsyth et al. 2008; Figure 1 and 3). The

105 offshore Canterbury Basin contains several late Cretaceous to Pleistocene buried

106 volcanoes and intrusive igneous bodies identified by seismic reflection mapping and

107 borehole data (e.g. Field et al. 1989; Blanke 2010; Bischoff et al. 2016; Barrier et al.

108 2017). Middle Miocene igneous rocks were first identified in the study area by the

109 petroleum exploratory Resolution-1 well, drilled in 1975 (Figure 1, 2 and 3). This

110 borehole penetrated volcaniclastic rocks interbedded with deep-water siltstones of

111 Waiauan age (12.7 to $11 \mathrm{Ma}$ ) from 1103.5 to $1220 \mathrm{~m}$ and intersected a coarse-grained

112 intrusive body at $1911 \mathrm{~m}$, which was K-Ar dated at $12 \pm 2 \mathrm{Ma}$ (Milne 1975).

113 Successive authors tentatively correlated the igneous rocks of Resolution-1 with

114 outcrops of volcanic rocks on the Banks Peninsula, the Acheron Outlier intrusions

115 (Milne 1975), and Harper Hills Basalt (Field et al. 1989; Figure 1). Banks Peninsula is a

116 large polygenetic composite-shield volcanic complex mainly erupted subaerially during

117 the late Miocene (Sewell 1988). Harper Hills Basalt comprises a sequence of subaerial

118 tholeiitic lava flows K-Ar dated at 10.5 $\pm 0.3 \mathrm{Ma}$ (Carlson et al. 1980; Browne 1983),

119 and associated volcanic muds (Coalgate Bentonites), basaltic dikes (Bluff Basalt), and

120 well-bedded volcaniclastic rocks (Sandpit Tuff). Biostratigraphic dating suggests that

121 the Sandpit Tuff dates either from Waiauan (12.7 to $11 \mathrm{Ma}$ ) or Tongaporutuan (11 to

122 7.2 Ma), according to Carlson et al. (1980) and Browne (1983). Acheron Outlier

123 intrusions are tholeiitic gabbros forming a large irregular laccolith emplaced along

124 Cretaceous to Paleocene paralic rocks of the Eyre Group, and were most likely formed 
125 in the Oligocene (Eady 1995). Carlson et al. (1980) identified early-to-middle Miocene

126 tuffaceous rocks interbedded with shallow marine to estuarine sedimentary strata

127 outcropping near Coalgate (Wairiri Volcaniclastite; Figure 1). These volcaniclastites

128 comprise volcanic silts, sands, and tuff-breccias that contain basaltic lava fragments,

129 glass, and abundant palagonite. Petrographically, Wairiri Volcaniclastite is the closest

130 outcropping correlative of the volcaniclastic rocks penetrated by Resolution-1, however

131 these volcaniclastites were erupted in a shallow-water environment, while

132 volcaniclastics of the MVF were erupted in a deep-water.

\section{Dataset, Methods and Limitations}

134 We use more than 40,000 km of high-quality 2D seismic lines in correlation

135 with data from six drilling wells (Leeston-1, Clipper-1, Ealing-1, Resolution-1;

136 Charteris Bay-1 and 2). Ten regional chronostratigraphic surfaces from the early

137 Miocene to the modern seabed were mapped in detail using 2D seismic lines. (Figure 1

138 and 2). Before mapping, the seismic reflection lines from the New Zealand Petroleum

139 and Minerals (NZPAM) Kingdom ${ }^{\odot}$ project were checked and calibrated with check-

140 shot surveys from the Resolution-1 and Clipper-1 wells (Milne, 1975 and Hawkes and

141 Mound 1984). The depths of chronostratigraphic markers and formation tops were

142 verified and, where necessary, corrected using the revised biostratigraphy of the

143 Canterbury Basin published by Schiøler et al. (2011). Subsequently, we mapped two

144 important early Miocene (eM) and late Miocene (lM) unconformities, based on the

145 stratal relationship of seismic reflectors including types of terminations and depositional

146 trends (Catuneanu 2006), and following criteria from "sequence boundary" defined by

147 Hunt and Tucker (1992). In addition, we have undertaken a seismic volcano-

148 stratigraphic analysis (Planke et al. 1999) for the study area by mapping the lateral

149 continuity of the pre- and post-eruptive surfaces (PrErS, PoErS) of the MVF (Figure 4). 
150 This mapping correlates the first and last occurrence of middle Miocene extrusive rocks

151 in the Resolution-1 well with seismic anomalies that could represent buried volcanoes

152 of the same age.

153 We described and photographed relevant rock intervals of the Resolution-1 at

154 the New Zealand Petroleum and Minerals core-store. One drill-core of an intrusive rock

155 from a depth of $1962.25 \mathrm{~m}$ and thirteen composite cutting samples of volcaniclastic

156 rocks at $10 \mathrm{~m}$ intervals between 1100 to $1230 \mathrm{~m}$ depth were used here to perform

157 macro-and-microscopic petrographic analysis. Petrographic characterization of these

158 cuttings samples may have limitations due to factors including, small original grain size,

159 potential break-up of material during drilling operations, composite sample intervals

160 that likely blend material from diverse beds, and the difficulty of separating drilling

161 mud from altered in situ volcanic fragments. Due to the high degree of alteration of

162 some of the cuttings samples, conventional sample washing to separate drilling mud

163 from sampled material was not applied because most of the soft rock material would

164 have been lost during the sieving process. Therefore, to prepare the samples we have

165 adopted a dry-and-wet manual "grain-by-grain" separation of potential volcanic

166 fragments from drilling mud. X-ray fluorescence (XRF), Scanning Electron Microscope (SEM) and Energy

168 Dispersive Spectroscopy (EDS) analysis were performed on samples from selected

169 intervals containing igneous rocks. Qualitative XRF was conducted using an Olympus

170 Vanta handheld analyzer for one sample from $1962.25 \mathrm{~m}$ depth (intrusion) and three

171 samples from 1130 to $1160 \mathrm{~m}$ depth (volcaniclastics). The handheld XRF machine was

172 calibrated to perform a bulk geochemistry analysis of the total sample. Although this

173 handheld cannot detect $\mathrm{Na}$, it can detect other essential ( $\mathrm{Si}, \mathrm{Ca}, \mathrm{K}, \mathrm{Ti}, \mathrm{Mg}$ ) and

174 incompatible elements $(\mathrm{Zr}, \mathrm{Y}, \mathrm{Ti}, \mathrm{Nb})$. Thus, we compare the chemical composition of 
175 the MVF intrusive and extrusive rocks using the $\mathrm{Zr} / \mathrm{Ti}$ versus $\mathrm{Nb} / \mathrm{Y}$ diagram proposed

176 by Pearce (1996) after Winchester and Floyd (1977). SEM and EDS analysis were

177 performed at the Electron Microscopy Centre at the University of Canterbury, with the

178 aim of characterizing the elementary chemical composition of fragments collected from

179 a depth range of 1140 to $1150 \mathrm{~m}$ (volcaniclastics), and to detail the morphology of the

180 volcaniclastic fragments.

181 Characterization of the Igneous Rocks and Enclosing Sedimentary Strata of 182 the MVF

183 The Resolution-1 borehole penetrates five main groups of rocks that comprise 184 and enclose the MVF. These are (from deepest to shallowest): (I) intrusive rocks

185 emplaced into (II) host paralic to neritic sedimentary rocks, (III) bathyal mudstones and

186 limestones, and (IV) bathyal siltstones interbedded with (V) volcaniclastic rocks.

187 Rock Association I: Intrusive rocks (1963 to $1911.5 \mathrm{~m}$ )

188 Resolution-1 penetrates $51.5 \mathrm{~m}$ of intrusive rocks from 1963 to $1911.5 \mathrm{~m}$, 189 approximately $5 \mathrm{~m}$ of which was cored from 1963 to $1958 \mathrm{~m}$. Petrographic description

190 of a core sample collected from a depth of $1962.25 \mathrm{~m}$ indicated a medium-grained,

191 hypidiomorphic olivine monzogabbro with ophitic and sub-ophitic textures (Figure 5).

192 The major mineral phases in this core sample are plagioclase $(70 \%)$, which forms

193 elongated euhedral to subhedral crystals ( 0.5 to $2.5 \mathrm{~mm})$, and clinopyroxene $(20 \%)$ that

194 occurs as subhedral prismatic crystals (up to $6 \mathrm{~mm}$ ). Prismatic subhedral orthoclase (1 -

$1952 \mathrm{~mm})$ and crystals of olivine $(1 \mathrm{~mm})$ occur in small amounts $(<5 \%)$, accompanied by

196 minor apatite and ilmenite $(<3 \%)$. Plagioclase crystals can be partially or totally

197 enclosed in prismatic crystals of clinopyroxene (ophitic and sub-ophitic texture),

198 suggesting that the plagioclase started to crystalize before clinopyroxene. These mineral 
199 phases and textures are typical of diabase rocks and suggest an intermediate magma

200 cooling rate at shallow depths (Walker 1957).

201 In some parts of the sample, the monzogabbro is altered to chlorite (Figure 5a, d

202 and g), which is interpreted to record effects of hydrothermal alteration at relatively

203 high temperature (ca $250^{\circ} \mathrm{C}$ ). The plagioclase (from andesine to labradorite

204 composition based on their extinction angle) is commonly altered to smectite, illite,

205 sericite and zeolite. The clinopyroxenes (augite) in some cases are replaced by

206 amphibole and biotite (Figure 5d). Subhedral olivine grains are in general fractured and

207 partially replaced by iddingsite, which indicates oxidizing conditions (Smith et al.

208 1987).

209 The petrographic description presented in Milne (1975) classified some parts of

210 this intrusion as a quartz-monzogabbro, and as a teschenite, due to the presence of

211 analcite. However, quartz crystals were absent in our samples, and we only identified

212 rare crystals of analcite associated with radial zeolite (Figure $5 \mathrm{a}$, $\mathrm{f}$ and $\mathrm{i}$ ), which always

213 occurs filling residual space and cavities. This suggests that analcite is more likely a

214 secondary product of hydrothermal alteration rather than a primary mineral that

215 originates from the melt. Miarolitic cavities were described in several parts of the core

216 (Figure 5f) reinforcing the petrographic interpretations of a hypabyssal rock injected at

217 shallow depths, and may indicate that MVF melts were enriched in volatiles

218 (Peretyazhko 2010).

219 Rock Association II: Paralic to neritic host sedimentary rocks (1911 to $1335 \mathrm{~m}$ ) The monzogabbro intrusion (Rock Association I) was emplaced into Cretaceous-

221 Paleocene paralic to neritic sedimentary rocks of the Broken River and Conway

222 formations (Rock Association II). These sedimentary rocks comprise granular pebble-

223 sized conglomerates, fine-grained white quartz sandstones, dark grey pyritic siltstones, 
and thin layers of carbonaceous mudstones. Abundant carbonate and zeolite veins indicate that hydrothermal activity extended at least $34 \mathrm{~m}$ above the intrusion (Milne 1975). Palynomorphs and miospores show an increasing degree of thermal alteration towards the intrusion (Schiøler et al. 2011). Onshore, similar gabbroid rocks (Acheron Outlier; for location see Figure 1) show thermal effects extending several tens of meters from the igneous rocks (Eady 1995). Intrusions emplaced in organic-rich sedimentary rocks have the potential to elevate the temperature near the igneous bodies sufficiently high to generate thermogenic gas (Aarnes et al. 2015). Heating of organic material can generate methane $\left(\mathrm{CH}_{4}\right)$, and release high amounts of greenhouse gases such as $\mathrm{CO}_{2}$ (Delmelle et al. 2015; Svensen et al. 2018) and $\mathrm{H}_{2} \mathrm{~S}$ (e.g. Iacono-Marziano et al. 2013;

234 Robertson et al. 2015; Arnorsson et al. 2015). The upper Paleocene-Eocene part of Rock Association II is characterized by mudstones and fine-grained sandstones (Charteris Bay Sandstone), interpreted to have

237 been deposited in a transgressive shallow-marine environment during passive subsidence of the basin (Field et al. 1989; Schiøler et al. 2011). Rock Association II is

239 locally interbedded with thin layers of tuffaceous rocks that likely correspond to 240 material erupted from scattered vents in the Canterbury Basin.

241 Rock Association III: Bathyal mudstones and limestones (1335 to $1284 \mathrm{~m}$ )

242 The light grey to brown mudstones (Ashley Mudstone) and light grey massive

243 limestones (Amuri Limestone and Omihi formations) of Rock Association III were 244 deposited during the Oligocene to early Miocene. These rocks are typically poorly indurated and comprise silty mudstones to calcareous mudstones and wackestones separated by gradational boundaries (Milne 1975; Figure 6). They also contain rare

247 tuffaceous material that likely erupted from scattered vents in the Canterbury Basin.

248 Rock Association III represents the time interval of maximum inundation of Zealandia, 
and in the study area, corresponds to the development of a condensed section attributed

250 to a low supply of terrigenous material (Field et al. 1989). The contact between the

251 Amuri and Omihi formations in the Resolution-1 well is unconformable, with a time

252 break of ca 13.5 million years, from the early Oligocene to early Miocene in the study

253 area (unconformity O-eM; Figure 3 and 6). The origin of the O-eM unconformity is

254 controversial and successive authors have interpreted it to be the product of glacio- or

255 tectonic-eustatic changes, sediment starvation during a high stand period, volcanism, or

256 action of sea-bottom currents (Lever 2007).

Rock Association IV: Bathyal siltstones (1284.1 to $686.1 \mathrm{~m}$ )

Rock Association IV comprises a soft light grey siltstone (Tokama Siltstone)

with sparse bioclasts and foraminifera fossils (Figure 7a). These rocks were deposited in a bathyal setting from the early Miocene to early Pliocene (Milne 1975; Schiøler et al. 2011). Rock Association IV is locally interbedded and blended with volcaniclastic material of the MVF (rocks association V; Figure 7b, c and d). Three main unconformities are identified by biostratigraphic data in this siltstone at the Resolution1 well, each representing hiatuses of 1 to $3 \mathrm{Ma}$ (Schiøler et al. 2011). These unconformities are interpreted to have formed by different tectonic pulses during the onset of basin inversion and contractional tectonics NW in the study area, which is related to southward propagation of the Neogene Hikurangi subduction zone (e.g. Field et al. 1989; Kamp et al. 1992; Lu et al. 2005; Schiøler et al. 2011). Here, we refer to these unconformities as eM (early Miocene), 1M (late Miocene), and eP (early Pliocene), according to their ages (Figure 3 and 6).

To characterize in detail the paleoenvironment in which the MVF has erupted, we subdivide the Tokama Siltstone into four depositional units. These units are bounded by unconformities or correlative marine conformities, recording major paleo- 
274 bathymetric changes identified in the biostratigraphic data of Resolution-1 (Schiøler et

275 al. 2011). Table 1; Figure 3 and 6 show the main stratigraphic and paleo-environment

276 characteristics of these units.

277 The lower Tokama was deposited during the late-early Miocene in a deep-to-

278 lower bathyal setting, with water depths ranging from 2000 to $1500 \mathrm{~m}$ (Figure 6). Its

279 upper boundary is marked by a sharp transition to a lower bathyal setting (1500 to 1000

$280 \mathrm{~m}$ ), which coincides with the unconformity eM, locally representing a ca 1.5 Ma hiatus

281 in sedimentation (Figure 6).

282 The middle Tokama was deposited during the middle Miocene, simultaneous

283 with volcanic activity in the MVF. This rock association formed in a relatively steady

284 lower bathyal setting (1500 to $1000 \mathrm{~m}$ deep), evident by the biomarker species

285 Sigmoilopsis schlumbergeri and Eggerella bradyi, often associated with Cibicides

286 robertsonianu. Up the well, the decreasing content of planktic species indicates an

287 overall decrease in water depths during the late-middle Miocene (Schiøler et al. 2011;

288 Figure 6). We place the onset of this base-level fall at ca $11 \mathrm{Ma}$, based on seismic

289 stratigraphic analysis that shows a NW-SE progradation of self-slope clinoforms, which

290 produces decreasing water depths in the study area (Figure 4).

The onset of decreasing water depths at ca 11 Ma marks the base of the upper

292 Tokama, which is interpreted to represent a progressive shift from a lower bathyal to a

293 middle bathyal setting (800-600 m). Seismic stratigraphy mapping demonstrates that

294 before $11 \mathrm{Ma}$, the volcanoes of the MVF were extinct (Bischoff et al. 2019b). The top

295 of the upper Tokama is marked by a sharp transition to an uppermost bathyal setting

296 (400-200 m) and associated hiatus of ca $1 \mathrm{Ma}$ in the study area (unconformity $1 \mathrm{M}$ ).

297 The uppermost Tokama (Figure 6) was deposited during the late Miocene to

298 early Pliocene in an uppermost bathyal setting. Seismic stratigraphic interpretation 
suggests a progressive shallowing in water depths up-sequence. The top of this

300 depositional unit is marked by the occurrence of bioclastic mudstones, coquinas and

301 sandstones of the Kowai Formation starting at $686.1 \mathrm{~m}$. Sediments of the Kowai

302 Formation mark the establishment of an outer neritic setting (100 to $200 \mathrm{~m}$ ) in the area

303 of the well, which occurred around 5.3 Ma (unconformity eP, Figure 3).

304 Rock Association V: Volcaniclastic rocks (1220 to $1103.5 \mathrm{~m})$

305 Rock Association V comprises poorly sorted, hyalocrystalline, altered and non-

306 welded fragments of leucocratic rocks, with frequent glassy shards and broken crystals

307 interbedded with the bathyal siltstones of Rock Association IV (Figures 7 to 12; Table

308 1). Grain-size distribution is variable $(<0.1$ to $5 \mathrm{~mm})$, usually comprising fragments

309 with microcrystalline, microporphyritic, vitrophyric, and less frequently, vitriclastic

310 textures (Figure 8). Primary components include crystals of plagioclase and pyroxene,

311 shards of glass (Figure 9 and 10), and spherical aggregates of microcrystals and

312 devitrified glass. Sandstone, coal and limestone lithics are abundant (Figure 7 and 11c

313 and f), showing petrographic similarities with those of Rock Associations II and III.

314 Pervasive palagonite alteration is dominant, although some fresh glass is also observed.

315 Elongated euhedral crystals of plagioclase are usually $<0.1$ to $1.5 \mathrm{~mm}$ in size,

316 and are typically associated with microporphyritic and vitrophyric textures (Figure 8).

317 Plagioclase often occurs as euhedral to anhedral broken phenocrysts in sharp contact

318 with the groundmass (Figure 8b, c and f). Some phenocrysts show rounded margins,

319 (Figure 8d) and some rare phenocrysts show sieve texture and devitrified glass

320 inclusions (Figure 8e).

321 Glassy shards are dominant and occur in a wide range of shapes and textures.

322 Commonly, shards are non-welded and present blocky and cuneiform shapes, and less

323 frequently, cuspate, platy and splintery shapes, and relics of bubble walls (Figure 9 and 
324 10). In some samples, these spall shards show jigsaw-fit texture, typically together with

325 blocky fragments containing a microporphyritic core (Figure 9). Very-fine anhedral

326 broken crystals often occur in association with shards showing cuspate, platy and

327 pumice shapes, typically together with pervasive alteration to palagonite (Figure 10).

328 The spherical aggregates of microcrystals and devitrified glass show two styles:

329 (i) poorly-indurated spherules with or without an inner core (possible a lithic fragment),

330 usually enveloped in a palagonite film (Figure 11a, $\mathrm{d}$ and e), and (ii) well-indurated

331 spherules that contain a devitrified (palagonite) inner core, a single concentric outer rim,

332 and an external array of acicular crystals in a radial pattern, typically associated with

333 perlitic cracks (Figure 12). In both styles, the spherical aggregates occur in association

334 with rocks showing a pervasive palagonite alteration.

335 Geochemistry of representative igneous rocks of MVF

336 The dominant mineral paragenesis comprising plagioclase, pyroxene and olivine

337 of both intrusive and extrusive rocks indicate that the volcanoes in the MVF, at least

338 partially, were sourced from primitive basaltic melts. XRF results for both

339 monzogabbro and volcaniclastic rocks indicates proportional content of $\mathrm{SiO}_{2}, \mathrm{Al}_{2} \mathrm{O}_{3}$,

$340 \mathrm{MgO}, \mathrm{Fe}_{2} \mathrm{O}_{3}, \mathrm{CaO}, \mathrm{K}_{2} \mathrm{O}_{5}, \mathrm{P}_{2} \mathrm{O}_{5}, \mathrm{TiO}_{2}$ and $\mathrm{MnO}$ (Appendix 1). The ratio of incompatible

341 elements of both rock types, when plotted in a $\mathrm{Zr} / \mathrm{Ti}$ versus $\mathrm{Nb} / \mathrm{Y}$ diagram (Pearce 1996;

342 after Winchester and Floyd 1977), suggests a basaltic alkaline magmatic series (Figure

343 13). The dominant palagonite alteration, which is typically interpreted as the product of

344 devitrification of sideromelane glass (Stroncik and Schmincke 2002), also indicates an

345 original basaltic composition. In addition, EDS analysis of volcanic glass fragments

346 reinforced a basaltic composition for the MVF melts (Appendix 2).

347 The similar compositional signature of all MVF igneous rocks can be interpreted

348 to indicate a genetic correlation between the monzogabbro intrusion and the middle 
349 Miocene volcaniclastic fragments. The close chemical relationship between intrusive

350 and extrusive volcanic rocks is consistent with data from seismic reflection lines in the

351 location of the well, which collectively suggest that these rocks formed in close spatial

352 and temporal association (Figure 14 and 15). It is important to recognize that the

353 geochemical analysis presented here was performed only to verify a possible

354 compositional correlation between the intrusive and extrusive rocks. Further detailed

355 geochemical studies are required to characterize the magmatic evolution of the MVF.

\section{Age and Formation of the MVF}

357 To estimate the age of active volcanism in the MVF, we consider

358 biostratigraphic data (Schiøler et al. 2011), a K-Ar date of the monzogabbro intrusion

359 (Milne 1975), sedimentological aspects of the strata that enclose both intrusive and

360 volcaniclastic rocks (i.e. amount of compaction and sedimentation rates), and results

361 from seismic stratigraphic mapping (Figure 6, 14 and 15). The oldest MVF

362 volcaniclastic rocks (1220 $\mathrm{m}$ in the well) coincide with the boundary between the

363 Lillburnian and the lower Waiauan New Zealand stages (ca 12.7 Ma), thus, we assume

364 an onset of volcanism in MVF at $12.7 \mathrm{Ma}$ (Figure 3 and 6). The youngest

365 volcaniclastics occur at $1103.5 \mathrm{~m}$ in the well, however, there is no direct

366 biostratigraphic age correlation at this depth (Figure 6). To define the cessation of

367 volcanic activity in the MVF, we calculated the sedimentation rates of the middle and

368 upper Tokama, for the depth interval between 1255 and $1030 \mathrm{~m}$ in the well (Figure 6).

369 The difference in thickness and age of this interval are $215 \mathrm{~m}$ and $2.59 \mathrm{Ma}$, respectively.

370 To reduce the effect of the thickness of volcanic rocks on sedimentation rates, we

371 subtract $10 \mathrm{~m}$, which was estimated from the density and gamma logs in the well

372 (Figure 6). This gives an average sedimentation rate of $83 \mathrm{~m} / \mathrm{Myr}$. Assuming that the

373 sedimentation rate was constant at Resolution-1 during the formation of the MVF, 
374 siltstone thickness of $106.5 \mathrm{~m}$ for the MVF interval would have been deposited over ca

375 1.2 Ma (i.e. $106.5 \mathrm{~m} / 83 \mathrm{Myr} / \mathrm{m}$ ). Thus, MVF volcanism started at ca $12.7 \mathrm{Ma}$ and may

376 have ceased at about 11.5 Ma, which is consistent with the K-Ar age of crystallization

377 of the intrusion (12 \pm 2 Ma; Milne 1975).

378 To estimate the depth of the saucer-shaped monzogabbro emplacement, we first

379 subtract the depth of the surface marking the onset of volcanism in the MVF $(1220 \mathrm{~m}$ in

380 the well), from the depth of the top of the intrusion in the well $(1911.5 \mathrm{~m})$, which

381 produces a difference of $691.5 \mathrm{~m}$. Next, we assume uniform compaction for the

382 overlying sedimentary pile of $40 \%$, using compaction curves for sediments in the

383 Canterbury Basin presented in Field et al. (1989). These calculations give us an

384 emplacement depth of ca $950 \mathrm{~m}$ below the contemporary middle Miocene paleo sea-

385 bed, which is consistent with the shallow level monzogabbro intrusion with ophitic

386 texture and miarolitic cavities. Results from the decompaction and backstripping of the

387 sedimentary overburden above the saucer-shaped monzogabbro presented in Magee et

388 al. (2019), suggest an emplacement depth of ca $800 \mathrm{~m}$ beneath the contemporaneous

389 middle Miocene surface, which is consistent with our results.

390 The age relationship of the monzogabbro and volcaniclastic rocks is reinforced

391 by seismic lines that show sedimentary strata force-folded into a dome shape above the

392 intrusive body. Middle Miocene sediments, including the volcaniclastics of the MVF,

393 onlap the uppermost termination of these folds. The doming consequentially changed

394 the Waiauan paleo-sea floor topography and promoted deposition as channelized

395 systems of latest Waiauan age (11.5 to $11 \mathrm{Ma}$ ) next to the dome structures (Figure 14).

396 Seismic lines that image the saucer-shaped monzogabbro show disrupted reflectors and

397 faults at the tips of this intrusive body, possibly representing pathways for magma and

398 hydrothermal fluid migration up-sequence (Figure 15). In some cases, these faults are 
connected with the root of volcanoes, indicating a possible feeding system for eruptions

400 onto the middle Miocene paleo-sea bed. Integration of results from petrography,

401 geochemistry and seismic interpretation suggests that the volcaniclastic rocks were at

402 least partially erupted by magmas sourced from the saucer-shaped monzogabbro. This

403 shallow intrusion has likely acted as a stationary magma chamber for some of the

404 volcanoes of the MVF.

\section{Discussion}

406 The volcanic textures recognized in this study confirm a volcanogenic origin of

407 the seismic anomalies previously interpreted to correspond to volcanoes buried in the

408 Canterbury Basin (Field et al. 1989). However, these textures could not provide all of

409 the necessary information to interpret past-eruptive styles of the volcanoes in MVF. For

410 example, broken phenocrysts of plagioclase with sharp edges (Figure 8) could represent

411 fragments of holocrystalline material crystalized in the magma chamber that was

412 disaggregated by pyroclastic or autoclastic processes when erupted at the surface

413 (McPhie et al 1993; Best and Christiansen 1997). The presence of phenocrysts with

414 rounded margins (Figure 8d) may be caused by abrasion due to particle collision during

415 magmatic transport, or mixing and recycling of material associated with multiple

416 explosions into deep crater zones of maar-diatreme volcanoes (White and Ross, 2011;

417 Graettinger et al. 2016). Shards with blocky, cuspate, platy, relics of bubble walls and

418 pumice shapes, together with very fine-grained rocks with a pervasive alteration to

419 palagonite (Figure 10) may indicate mechanisms of intense fragmentation such as those

420 experienced in phreatomagmatic eruptions (e.g. Walker and Croasdale 1971; McPhie et

421 al. 1993). However, White and Valentine (2016) argue that the particle morphology and

422 fragment size may not contain all the necessary information to diagnose the products of

423 magmatic versus phreatomagmatic eruptions. These spall shards with jigsaw-fit texture, 
424 in association with blocky fragments with microporphyritic cores could represent

425 fragments of hyaloclastites or could be formed at the chilled crust of submarine spatter-

426 like deposits (Cas and Giordano 2014; Cas and Simmons 2018). The spherical-shaped

427 fragments (Figure 11 and 12) may represent both armoured lapilli formed as a product

428 of eruption-fed density currents (White 2000; Agirrezabala et al. 2017), and/or

429 spherulites, which are commonly interpreted to indicate high-temperature devitrification

430 of coherent volcanic glass (Marshall 1961; Lofgren 1970; apud McPhie et al. 1993).

431 Combining petrographic and seismic reflection interpretations constrains the

432 eruptive styles in the MVF. Near the location of Resolution-1, seismic imagery shows

433 deep craters excavated into the PrErS horizon (Figure 4 and Figure 15). The roots of

434 these craters terminate at the depth of the underlying Eocene-Oligocene limestone and

435 sandstone units, which likely provide the common lithic fragments found in the MVF

436 volcaniclastic rocks (Figure 11). Deep excavations into the PrErS requires significant

437 energy and intense material fragmentation (e.g. Lorenz 1985; Zimanowski et al. 1997;

438 Kereszturi and Németh 2013; White and Valentine 2016), which together with the

439 textures of the volcaniclastic rocks may be strong evidence of phreatomagmatic activity

440 in the MVF. The presence of frequent lithics of coal (Figure 7), possibly from the

441 underlying Cretaceous Broken River Formation, may indicate that thermogenic gases

$442\left(\mathrm{CH}_{4}\right)$ or $\mathrm{CO}_{2}$ could be incorporated into the magmatic system. The addition of these

443 coeval gases can contribute significantly to the overpressure necessary to form large

444 deep-water pyroclastic eruptions, as proposed by Svensen et al. (2004) and Agirrezabala

445 et al. (2017) for example.

446 Given the uncertainties and limitations of using small cutting samples from

447 borehole data, it was not possible to confidently interpret the origin of the

448 volcaniclastics rocks as primary eruptive or resedimented deposits. Some volcanic 
textures (rounded clasts and polymictic material) together with volcaniclastic material

450 occurring mixed with the Tokama Siltstone, suggest some degree of reworking of these

451 deposits. However, mixing of volcaniclastics and siliciclastic material may be caused by

452 drilling issues or could represent the distal products of submarine pyroclastic plumes

453 that incorporated lithics from the Tokama Siltstone during magma fragmentation and

454 transport (White 2000). In contrast, wireline-logs of Resolution-1 show sharp log-facies

455 contacts at the boundaries between volcaniclastics and siltstones (Figure 6), which

456 commonly indicate abrupt compositional changes in lithofacies and could point towards

457 a primary volcaniclastic deposit. In addition, seismic facies corresponding to the

458 volcaniclastic interval show constant lateral thickness and are not confined to valleys

459 (Figure 14), a characteristic of subaerial pyroclastic surge deposits (Cas and Wright

460 1992). This constant lateral thickness may indicate similar processes to those observed

461 in deposits of eruption-fed density currents (White 2000). These observations reinforce

462 the view that both end members, primary and reworked volcaniclastics, could be present

463 in Resolution-1. In light of these uncertainties, integration of petrography, seismic

464 stratigraphy and biostratigraphic data indicate that these volcaniclastic rocks were: i)

465 erupted onto sediments deposited in a deep-water setting (ca 1000 to $1500 \mathrm{~m}$ ), ii) likely

466 experienced pyroclastic and possibly autoclastic fragmentation, iii) may or may not

467 have been reworked, and iv) deposited next to the volcanoes pc14, nf02 and nf03

468 (Figure 4 and 15). These evidences suggest that volcaniclastic rocks of association $\mathrm{V}$

469 may represent volcanogenic deposits erupted from diverse volcanoes. Although some of

470 the volcanic textures more likely indicate a pyroclastic origin, their analysis alone could

471 not provide enough evidence to define the MVF past-eruptive styles. Insights from

472 seismic reflection data enriched these interpretations. 


\section{Conclusions}

Volcaniclastic and intrusive rocks collected from the Resolution-1 well confirm a magmatic origin of the anomalies observed in seismic lines in the study area. In seismic imagery, these volcanic anomalies form a cluster of middle Miocene volcanoes and correlative intrusive bodies, here referred as the Maahunui Volcanic Field (MVF). Integration of the results from this and previous work suggests that magmatic activity in MVF was active from ca 12.7 to $11.5 \mathrm{Ma}$. The magmatic products representative of MVF melts are primarily alkalic basalts in composition. Miarolitic cavities and ophitic texture observed in the monzogabbro penetrated by Resolution-1 indicate that the saucer-shaped intrusion imaged in seismic lines was injected at shallow depths of ca $950 \mathrm{~m}$ below the middle Miocene MVF paleo-sea floor. Integration of petrographic, geochemical and seismic interpretation indicate that the volcaniclastic rocks likely have a genetic relationship with the saucer-shaped monzogabbro. This shallow intrusive body possibly served as a stationary magma chamber that fed eruptions onto the middle

487 Miocene paleo-seafloor. Biostratigraphic data suggest that these eruptions occurred in a lower bathyal setting (1000 - $1500 \mathrm{~m}$ depth) in the vicinity of Resolution-1. High contents of glass shards, relics of bubble walls, presence of spheroidal aggregates enveloped in palagonite films (possibly armoured lapilli), broken phenocrysts, and lithics, suggest possible pyroclastic mechanisms of fragmentation. This interpretation is supported by the seismic morphology of the volcanoes in the MVF, which indicate material fragmentation and particle dispersion comparable to those produced by phreatomagmatic eruptions, although this eruptive style is rarely considered to occur in deep-waters (ca $1000 \mathrm{~m}$ ). The emplacement of intrusive bodies into organic-rich sedimentary rocks of the Broken River Formation could incorporate thermogenic gases

497 into the magmatic system, contributing with the overpressure necessary to form large deep-water pyroclastic eruptions. This study demonstrates the value of combining 
499 insights from petrographic analysis with seismic reflection interpretation to investigate

500 the formation of ancient volcanoes now buried in sedimentary basins.

501

502

$503 \quad$ List of tables

504 Table 1: Main stratigraphic and paleoenvironmental characteristics of Rock Association

505 IV. The highlighted middle Tokama depositional unit (red) is interbedded with the

506 volcaniclastic rocks of the MVF. These rocks were deposited in a lower bathyal setting

507 (1500-1000 m water depths).

\begin{tabular}{|c|c|c|c|c|c|c|}
\hline $\begin{array}{l}\text { Depositional } \\
\text { unit }\end{array}$ & $\begin{array}{l}\text { Depth in } \\
\text { the well }\end{array}$ & Age & $\begin{array}{c}\text { Depositional } \\
\text { setting }\end{array}$ & $\begin{array}{l}\text { Lower } \\
\text { bound }\end{array}$ & $\begin{array}{l}\text { Upper } \\
\text { bound }\end{array}$ & $\begin{array}{c}\text { Thickness } \\
\text { (m) }\end{array}$ \\
\hline $\begin{array}{l}\text { Uppermost } \\
\text { Tokama }\end{array}$ & $\begin{array}{l}1016 \text { to } \\
686.1\end{array}$ & $\begin{array}{l}\text { Late-early } \\
\text { Miocene to } \\
\text { late Pliocene }\end{array}$ & $\begin{array}{l}\text { Uppermost } \\
\text { bathyal }\end{array}$ & Unc. IM & Unc. eP & 329.9 \\
\hline $\begin{array}{l}\text { Upper } \\
\text { Tokama }\end{array}$ & $\begin{array}{l}1070 \text { to } \\
1016\end{array}$ & $\begin{array}{l}\text { Late-early } \\
\text { Miocene }\end{array}$ & Mid bathyal & $\begin{array}{l}\text { Onset of slope } \\
\text { progradation }\end{array}$ & Unc. IM & 54 \\
\hline $\begin{array}{l}\text { Middle } \\
\text { Tokama }\end{array}$ & $\begin{array}{l}1269 \text { to } \\
1070\end{array}$ & $\begin{array}{l}\text { Middle } \\
\text { Miocene }\end{array}$ & $\begin{array}{l}\text { Lower bathyal } \\
(1500-1000 \mathrm{~m})\end{array}$ & Unc. eM & $\begin{array}{l}\text { Onset of slope } \\
\text { progradation }\end{array}$ & 190 \\
\hline $\begin{array}{l}\text { Lower } \\
\text { Tokama }\end{array}$ & $\begin{array}{l}1284.1 \text { to } \\
1269\end{array}$ & $\begin{array}{l}\text { Late-early } \\
\text { Miocene }\end{array}$ & $\begin{array}{l}\text { Deep-lower } \\
\text { bathyal }\end{array}$ & Omihi Fm & Unc. eM & 24 \\
\hline
\end{tabular}




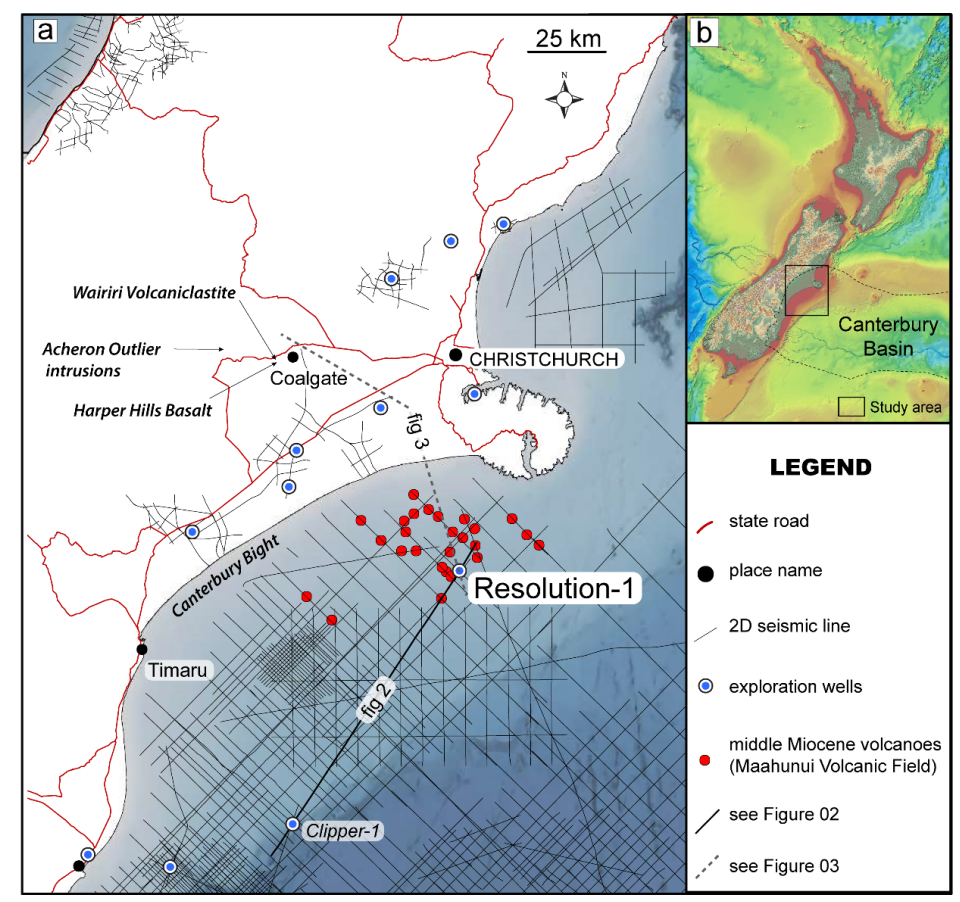

511 Figure 1: a) Map showing the location of volcanoes of the MVF (red dots) mapped from

512 2D seismic reflection lines (thin black lines). b) New Zealand topographic and

513 bathymetric map (NZ Petroleum Exploration 2018 datapack) showing the location of 514 the study area. 


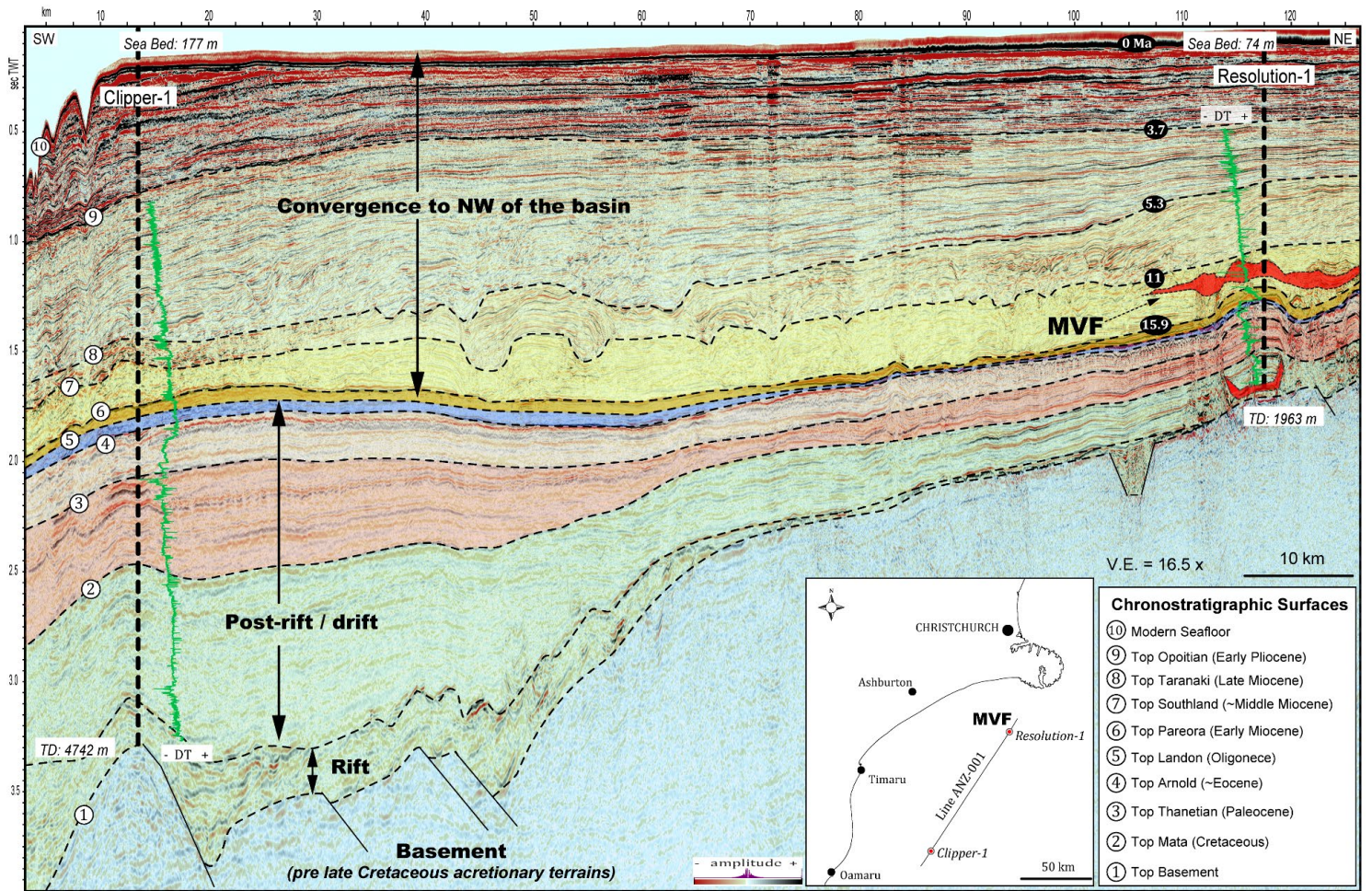

517 Figure 2: 2D regional strike/oblique seismic line showing the location of the MVF (red)

518 and its location in the basin succession. The Resolution-1 and Clipper-1 wells were used

519 to tie the seismic data to chronostratigraphic surfaces (1 to 10) that represent important

520 changes during the evolution of Canterbury Basin. 


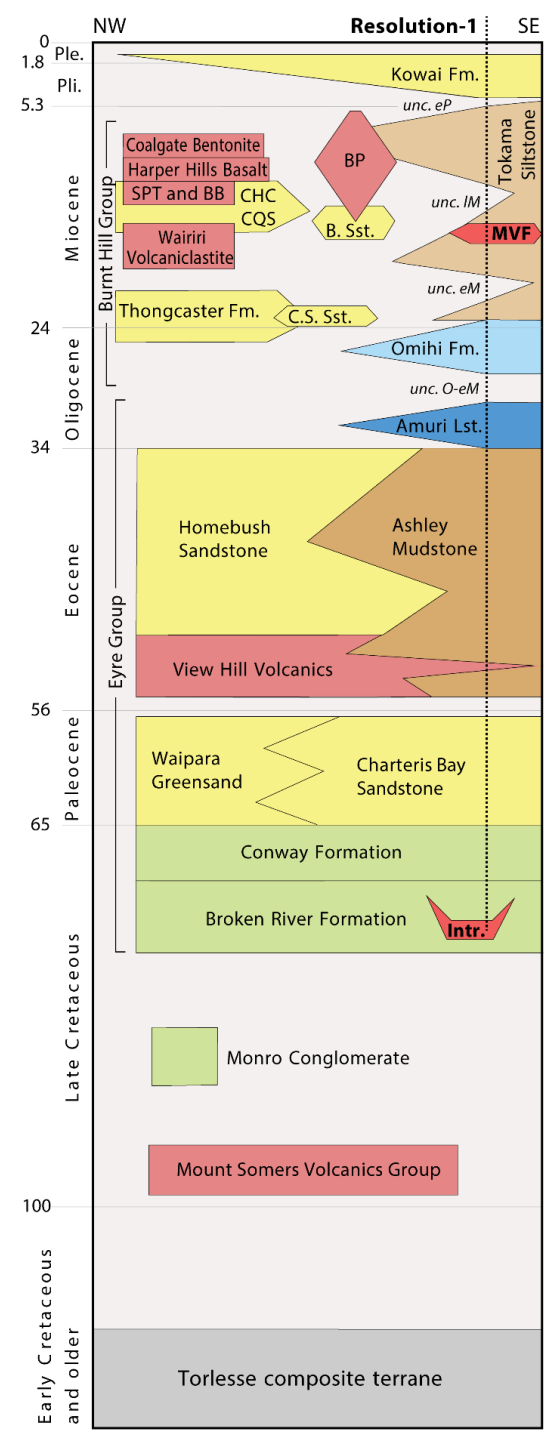

523 Figure 3: Simplified Cretaceous and Cenozoic chronostratigraphic chart of the northern

524 Canterbury Basin. Abbreviations are: middle Miocene monzogabbro intrusion (Intr.),

525 Curiosity Shop Sandstone (C.S. Sst.), Bradley Sandstone (B. Sst.), Chalk Quarry

526 Sandstone (CQS), Chalk Hill Clay (CHC), Maahunui Volcanic Field (MVF), Banks

527 Peninsula volcanics (BP), Sandpit Tuff (SPT) and Bluff Basalt (BB). Age of

528 unconformities in the Resolution-1 well are: Oligocene-early Miocene (O-eM), early

529 Miocene (eM), late Miocene (lM) and early Pliocene (eP). After Carlson et al. (1980),

530 Field et al. (1989), Forsyth et al. (2008), Schiøler et al. (2011) and Boyes et al. (2012). 

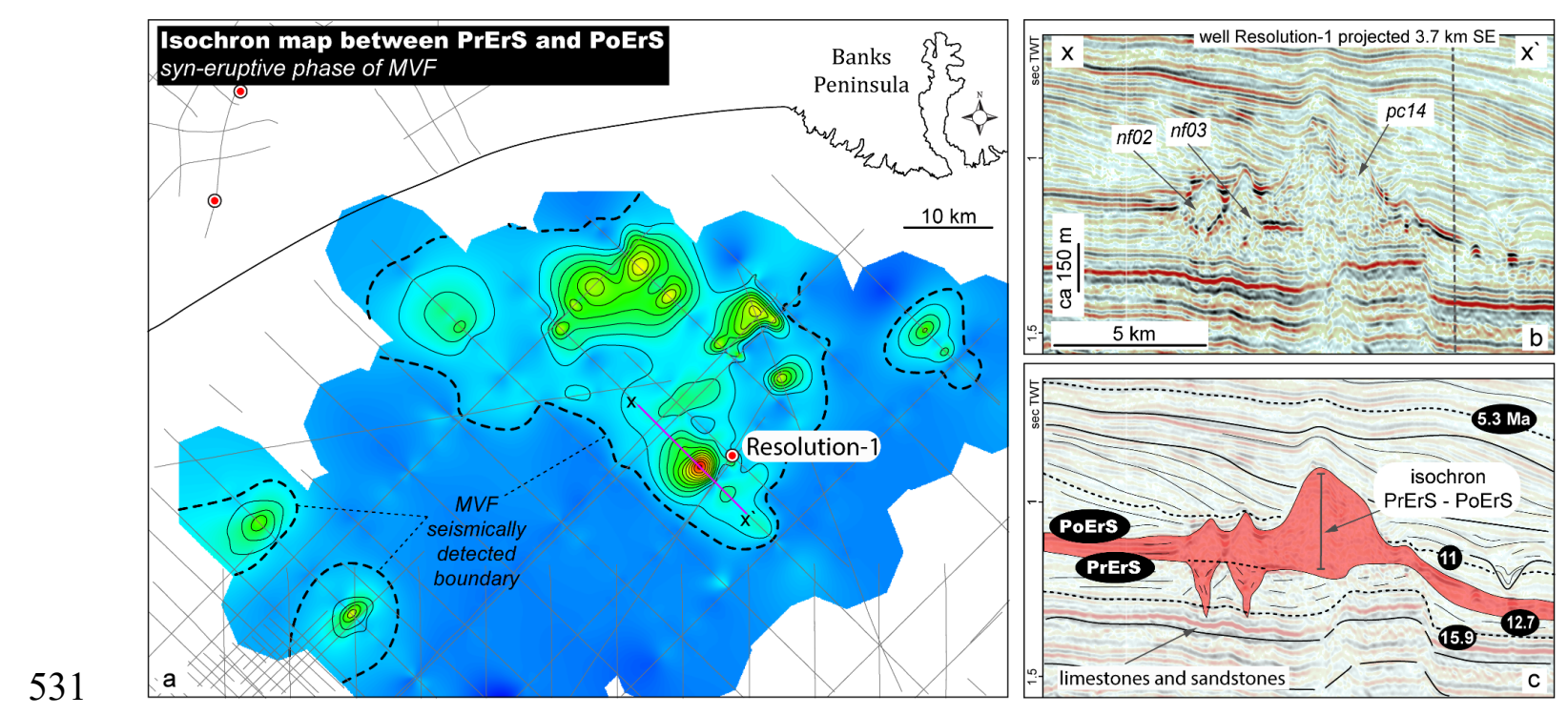

532 Figure 4: a) Isochron map between pre-eruptive (PrErS) and post-eruptive surfaces

533 (PoErS) of the MVF showing the locations of cone-type volcanoes. Note that the

534 surfaces thin and amalgamate with increasing distance from individual or clusters of

535 volcanoes, defining the seismic detectable boundaries of the MVF. (b) Uninterpreted

536 and (c) interpreted seismic line across volcanos pc14, nf02 and nf03. Negative

537 structures (nf02 and nf03) were excluded during mapping of the PrErS surface due to

538 computer limitations, as they would have shown a false positive structure on the

539 isochron map. 

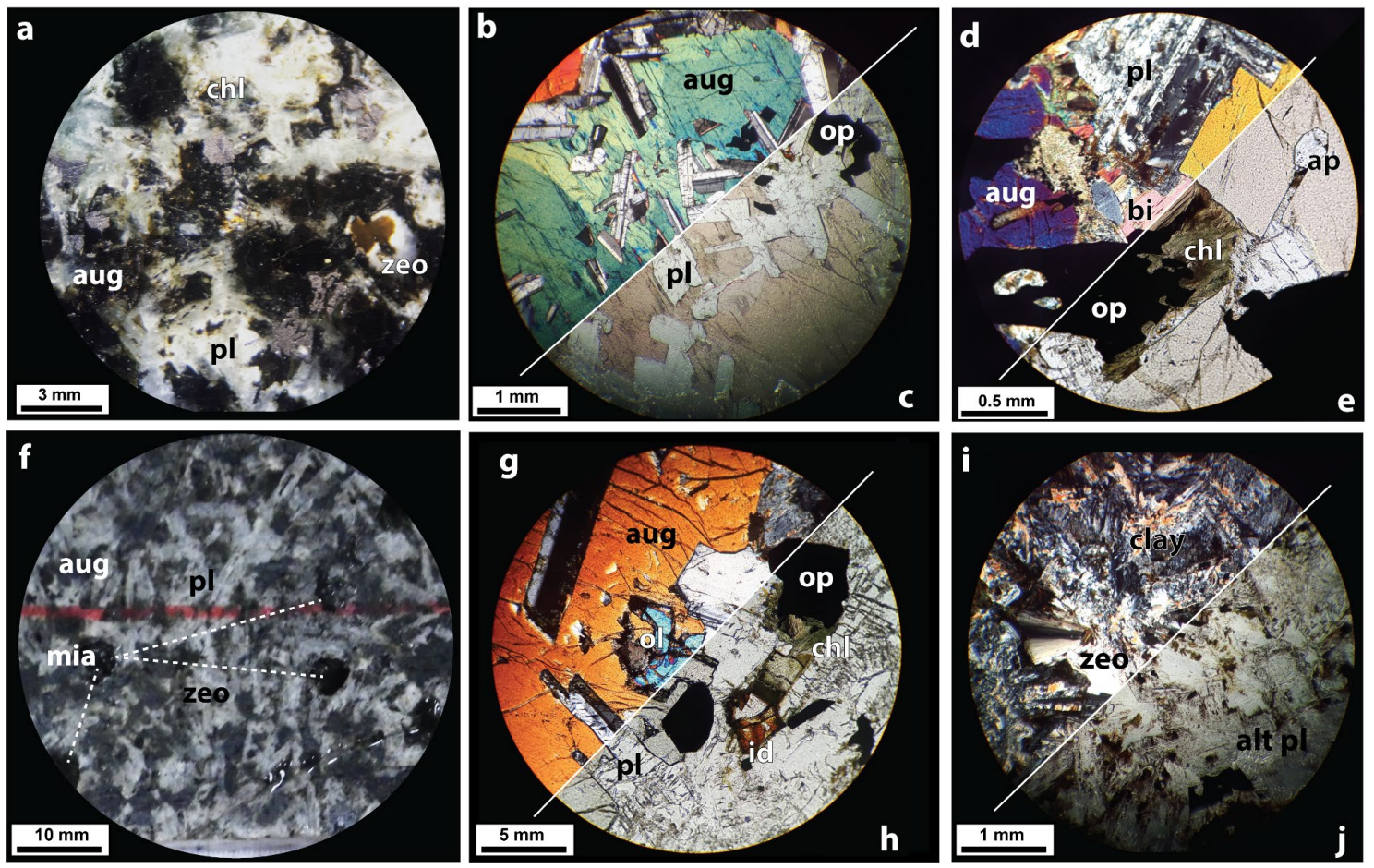

542 Figure 5: (a and f) Medium-grained monzogabbro recovered from a depth of $1962.25 \mathrm{~m}$,

543 showing plagioclase ( $\mathrm{pl}$ ), pyroxene (aug), chlorite (chl), zeolite (zeo) and miarolitic

544 cavities (mia). (b, d, g and i) Thin-sections in cross-polarized light showing ophitic

545 texture of plagioclase and augite, olivine (ol) crystals partially replaced by iddingsite

546 (id), augite replaced by biotite (bi) and chlorite, radial zeolite filling interstitial space

547 and plagioclase replaced by clays (alt pl). Accessory minerals are opaques (op) and

548 apatite (ap). (c, e, h and j) show the same thin sections in plain-polarized light. 


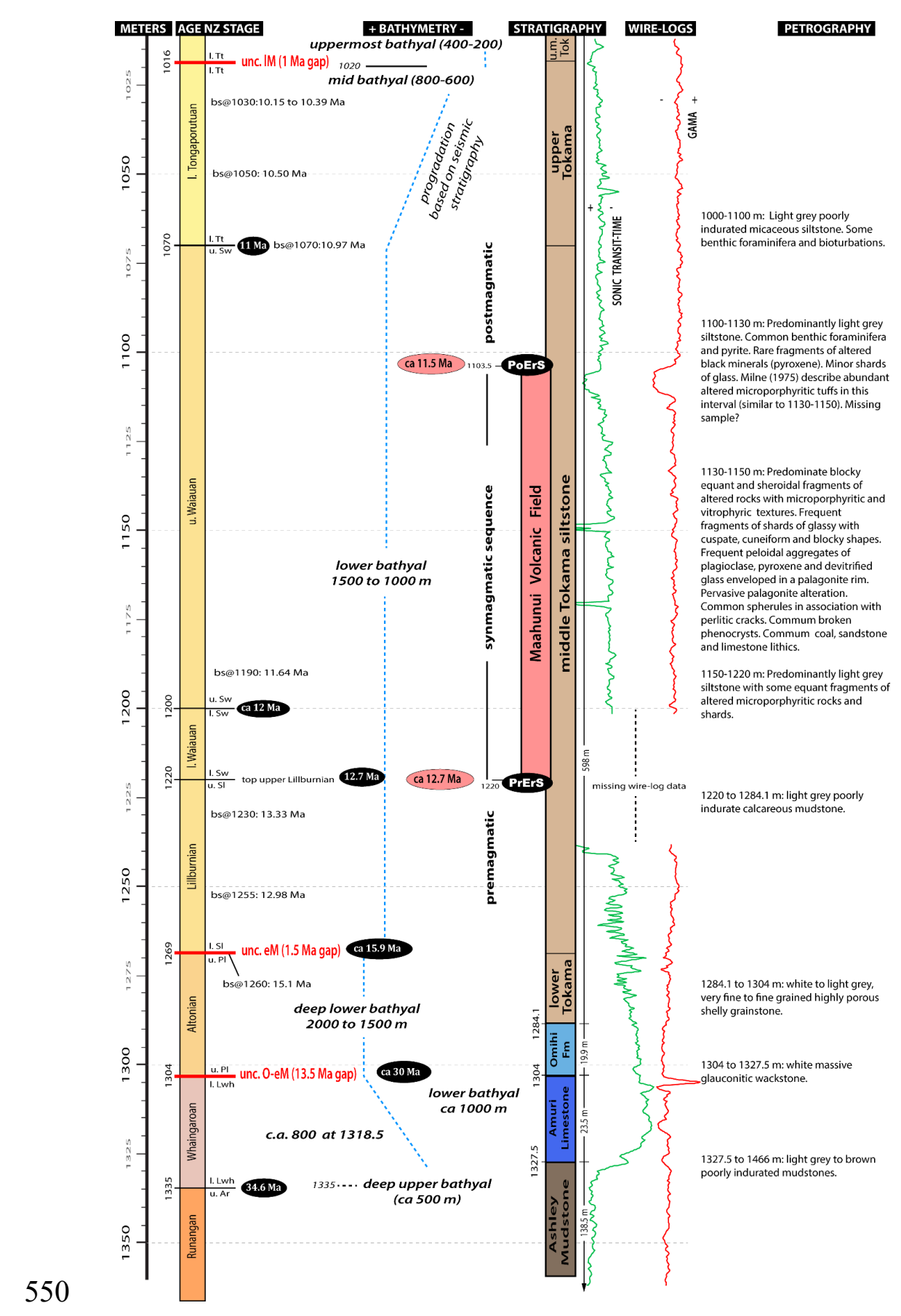

551 Figure 6: Composite data of the Oligocene-Miocene interval of the Resolution-1 well

552 showing the lithologies, ages, paleoenvironments, stratigraphy, and wire-logs. Symbols

553 “bs@” give the biostratigraphic age of Schiøler et al. (2011). Blue dashed lines show

554 the bathymetric trend. Numbers in black ellipses are ages derived using the $2015 \mathrm{NZ}$

555 Geologic Time Scale (Raine et al. 2015). Numbers in red ellipses are estimated ages of

556 the MVF based on the integration of insights from seismic reflection lines with

557 radiometric dating of igneous rocks representative of the MVF, and biostratigraphy

558 analysis of the enclosing sedimentary strata. 

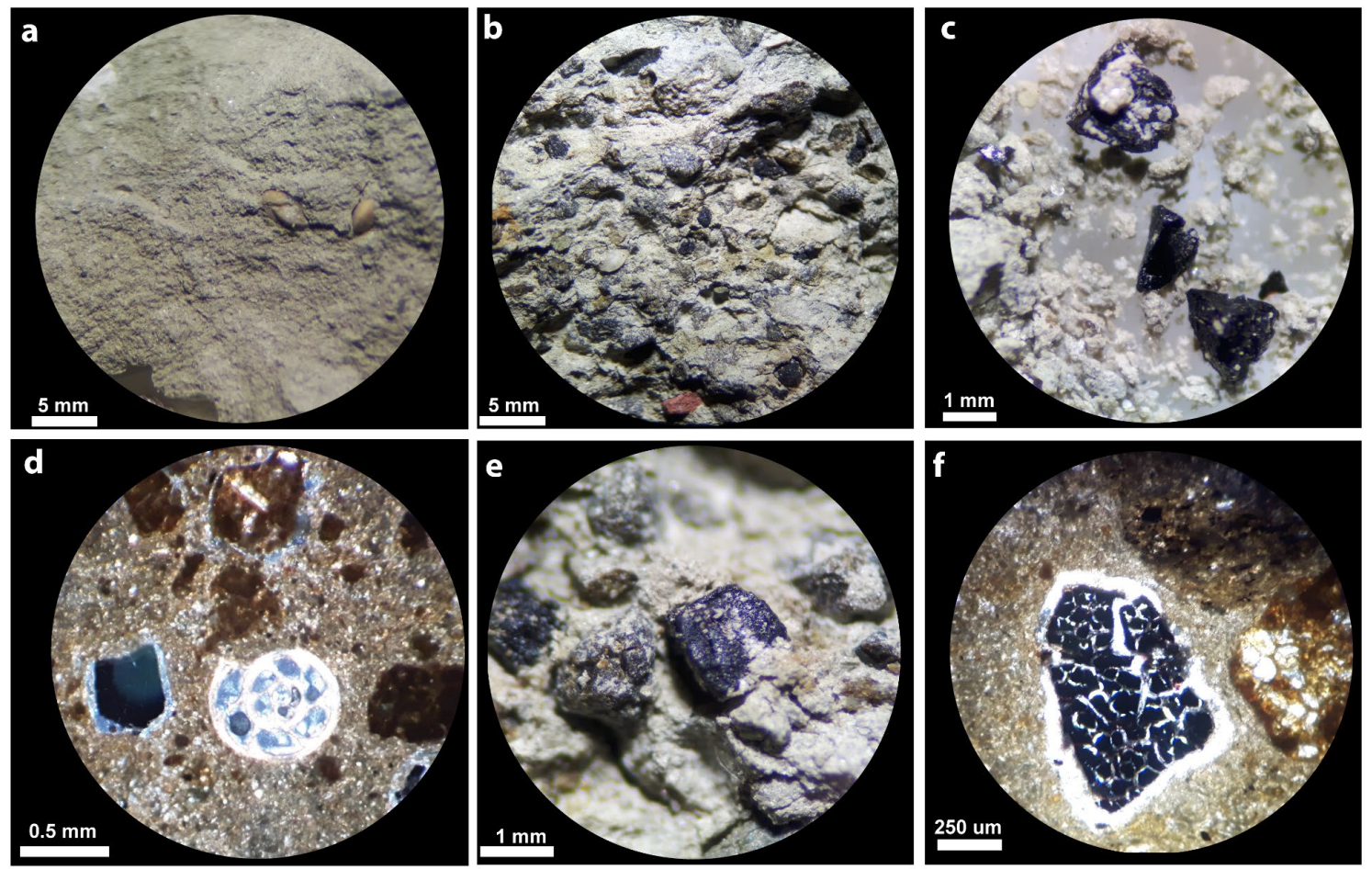

560 Figure 7: (a) Unwashed cutting samples of the middle Tokama depositional unit (Rock

561 Association IV) recovered from the interval 1130 to $1120 \mathrm{~m}$ showing a massive

562 siltstone with foraminifer fossils. (b, $c$ and e) Unwashed cutting samples of the Rock

563 Association V (1140-1130 m) showing volcanic fragments, coal lithics, bioclasts, and

564 altered crystals of pyroxenes (detailed in e). Thin section in cross-polarized light (d) and

565 plain-polarized light (f) showing an unwashed cutting sample comprising a gastropod

566 fossil, coal lithics, and volcanic fragments with pervasive palagonite alteration. 

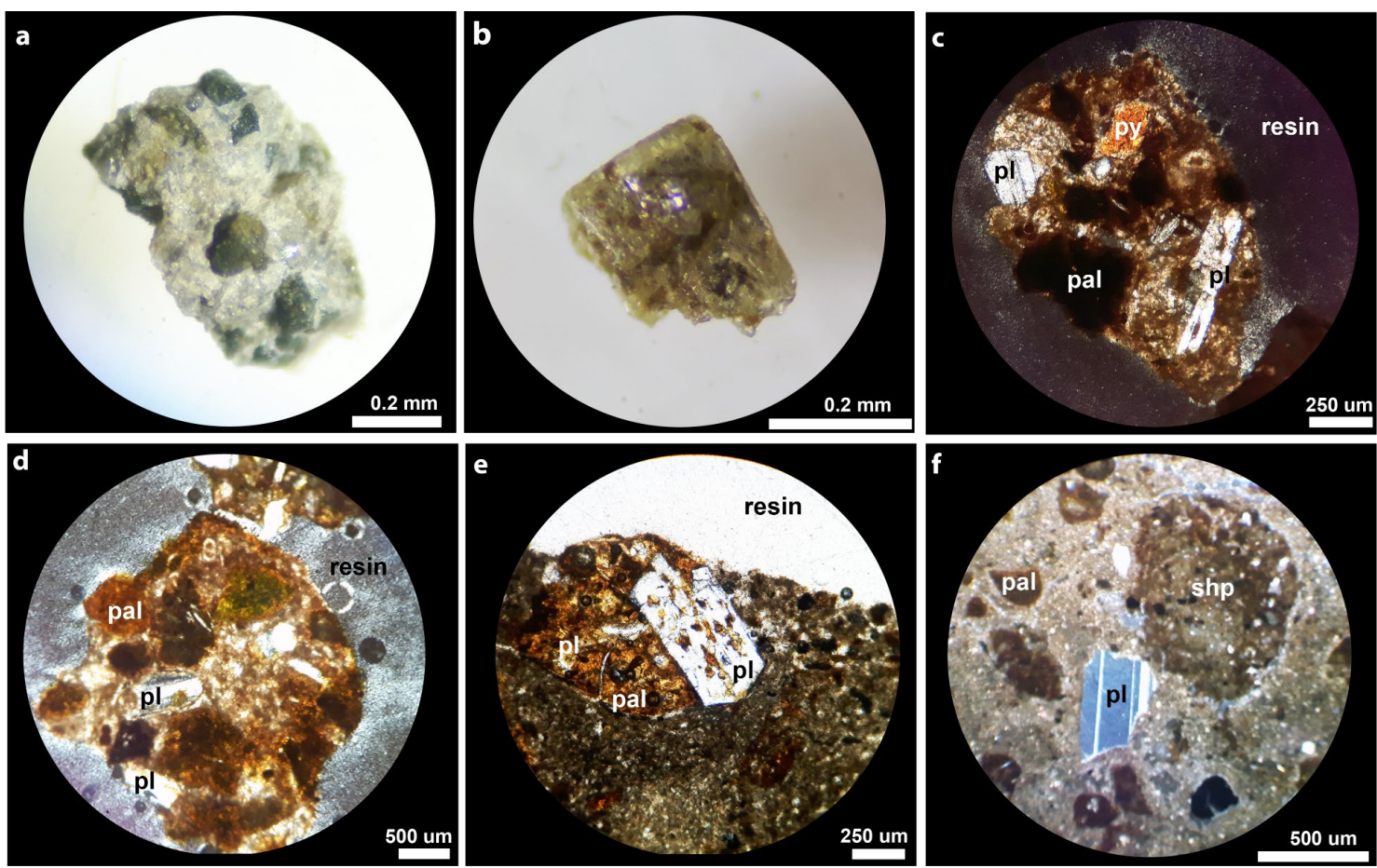

568 Figure 8: Washed (a to d) and unwashed (e and f) cutting samples of Rock Association

$569 \mathrm{~V}$ collected from the depths of 1140 to $1130 \mathrm{~m}$ in Resolution-1. (a) A loose fragment of

570 an aggregate of plagioclase (pl) and pyroxene (py) phenocrysts. (b) An example of a

571 broken plagioclase fragment. (c to e) Thin sections in cross-polarized and plain-

572 polarized light (e) showing volcaniclastic fragments with microporphyritic and

573 vitrophyric textures. Note the plagioclase with rounded borders (d) and the anhedral

574 broken crystals (c and f). Fragments with spherical shapes (shp) are commonly

575 observed in the Rock Association V (f). 

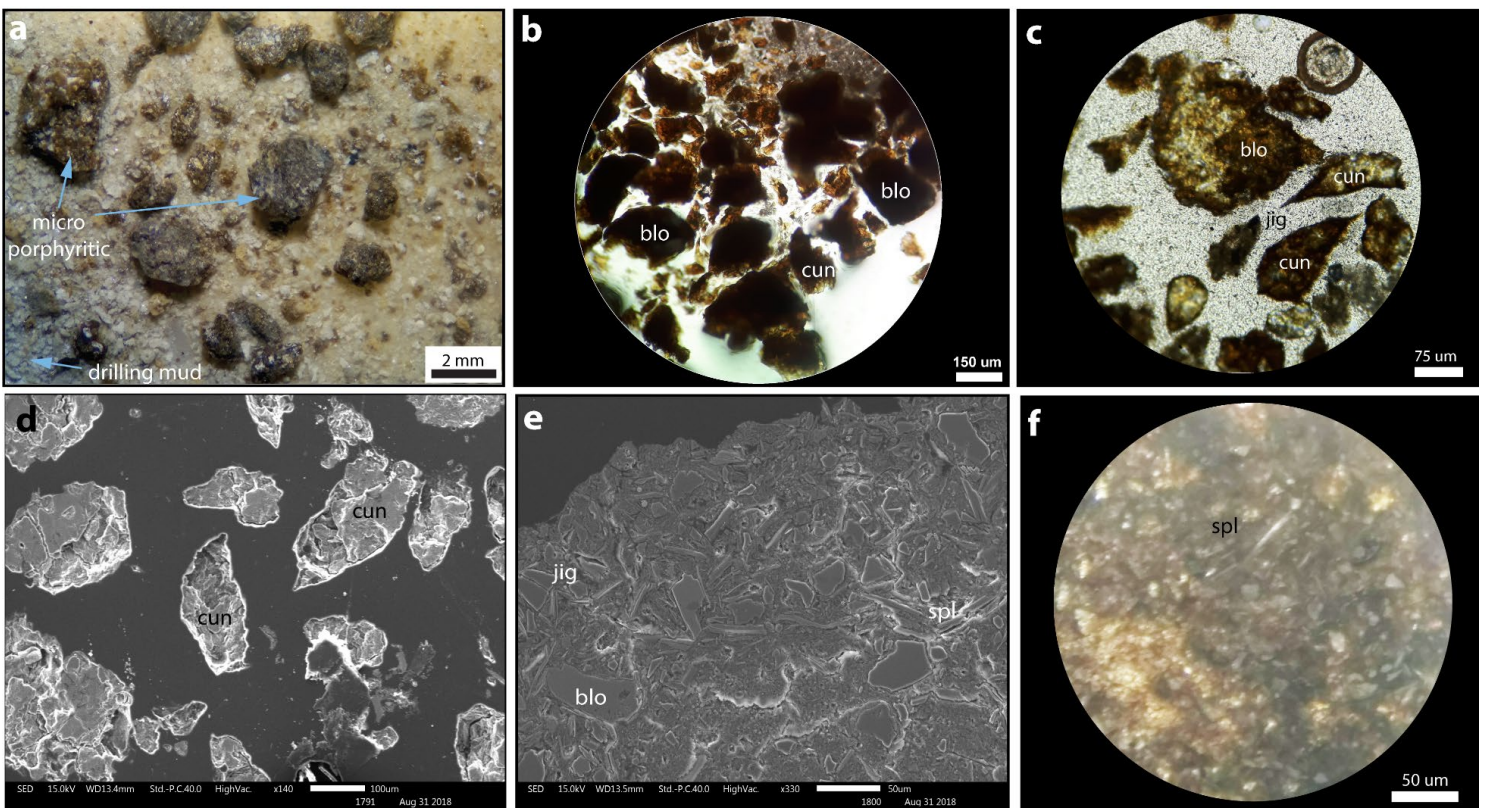

578 Figure 9: Washed cutting samples of the Rock Association V collected from the depths

579 of 1140 to $1130 \mathrm{~m}$ in Resolution-1. (a) Well cuttings submerged in water during the

580 washing process showing altered blocky equant volcaniclastic fragments with

581 microporphyritic texture. Thin sections in plain-polarized light (b, c and f) and SEM

582 images ( $\mathrm{d}$ and e) showing spalls of glassy shards with cuneiform (cun), blocky (blo) and

583 splintery (spl) shapes within a jigsaw-fit (jig) texture.

584 

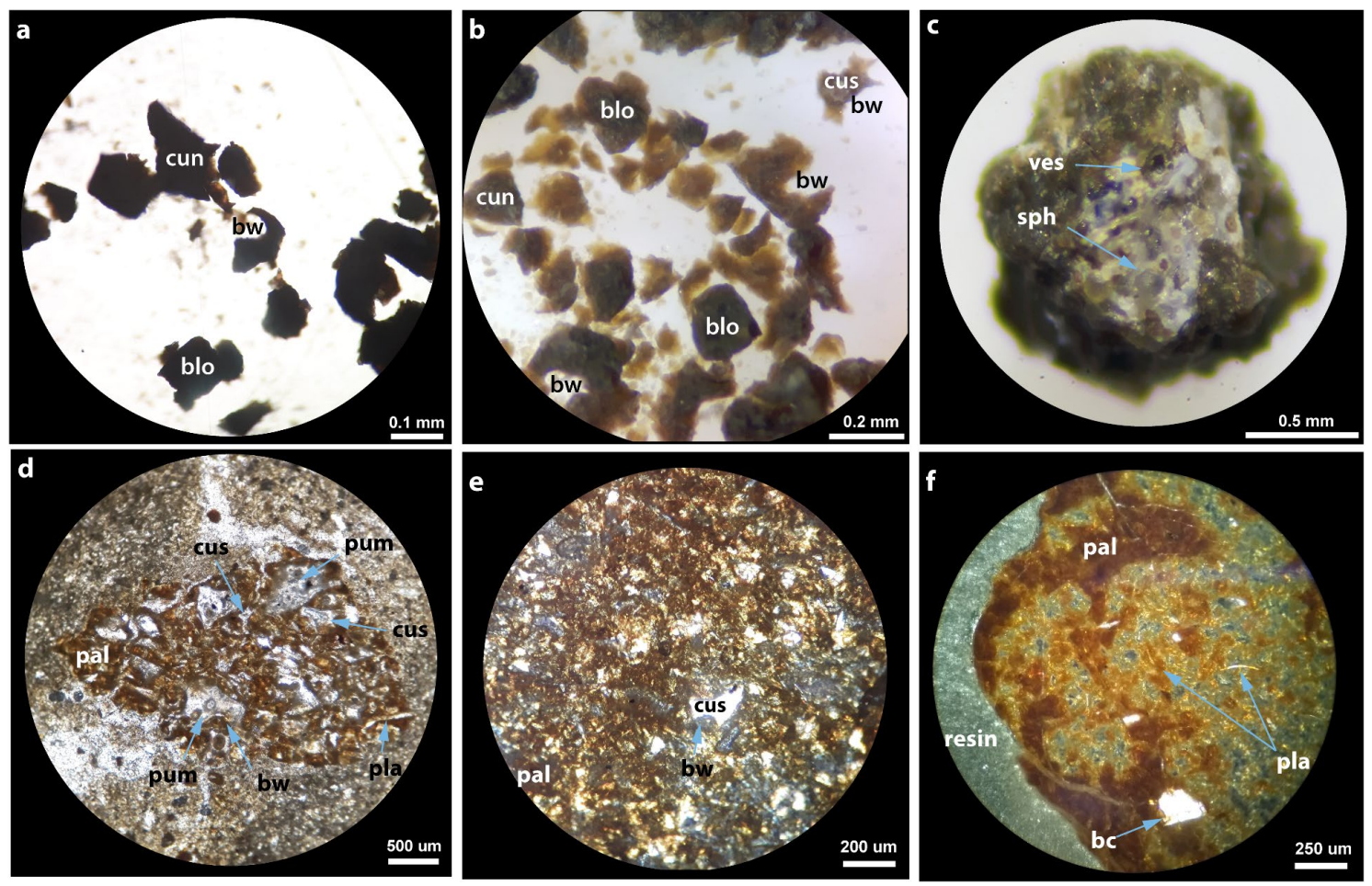

587 Figure 10: Washed cutting samples of the Rock Association V collected from the depths

588 of 1130 to $1140 \mathrm{~m}$ in Resolution-1. (a, b and c) Loose fragments of shards with cuspate

589 (cus), cuneiform (cun), blocky (blo) and platy (pla) shapes, relic bubble walls (bw),

590 spherules (sph) and vesicles (ves). Thin sections in cross-polarized (d and e) and plain-

591 polarized light (f) showing shards with cuspate, platy and pumice (pum) shapes in

592 association with fragments of broken crystals (bc) and pervasive palagonite (pal)

593 alteration. 

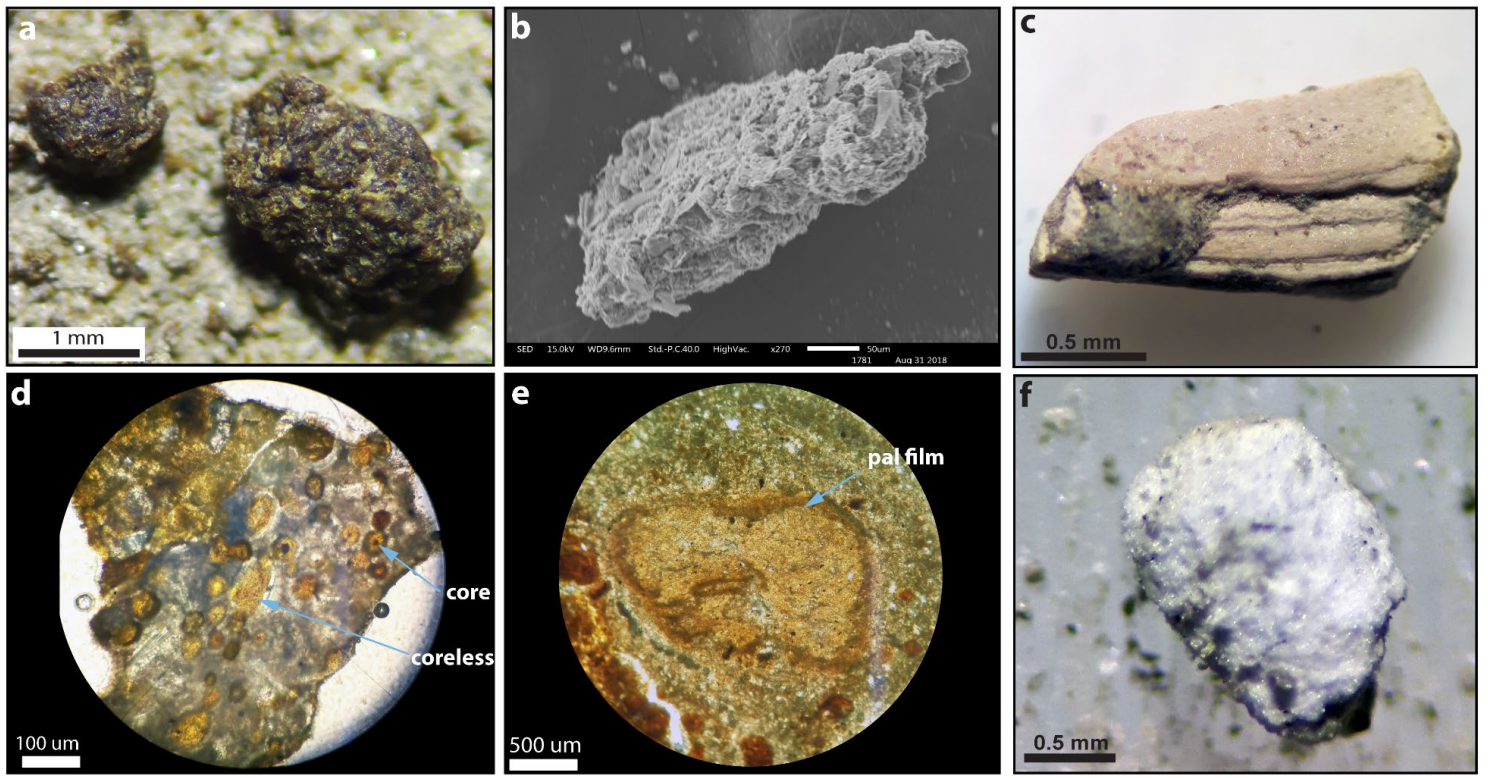

596 Figure 11: Washed cutting sample (a) and SEM image (b) of loose, poorly-indurated

597 aggregates of microcrystals and sharp fragments of glass from the interval 1140 to 1130

$598 \mathrm{~m}$ in Resolution-1. Thin-sections in plain-polarized (d) and cross-polarized (e) light

599 showing core (possible a lithic fragment) and coreless fragments with a spherical shape

600 enveloped in a palagonite (pal) film. Loose limestone (c) and sandstone (f) fragments

601 collected from the interval of 1140 to $1130 \mathrm{~m}$. These rocks are lithics found within the

602 volcaniclastics of the Rock Association V, and are petrographically similar to the

603 underlying limestones and sandstones of Rock Associations II and III.

604

605 

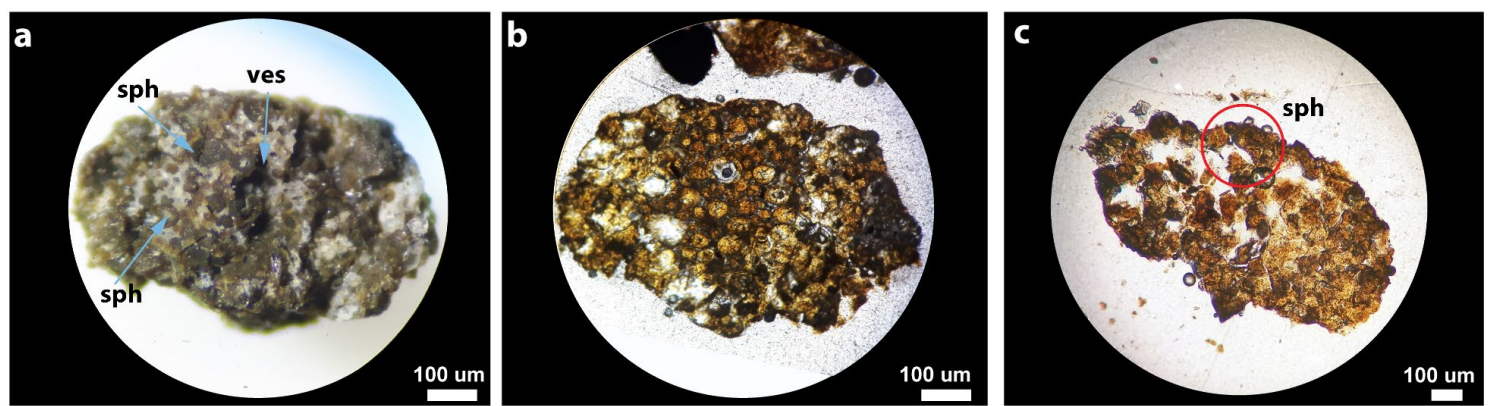

606
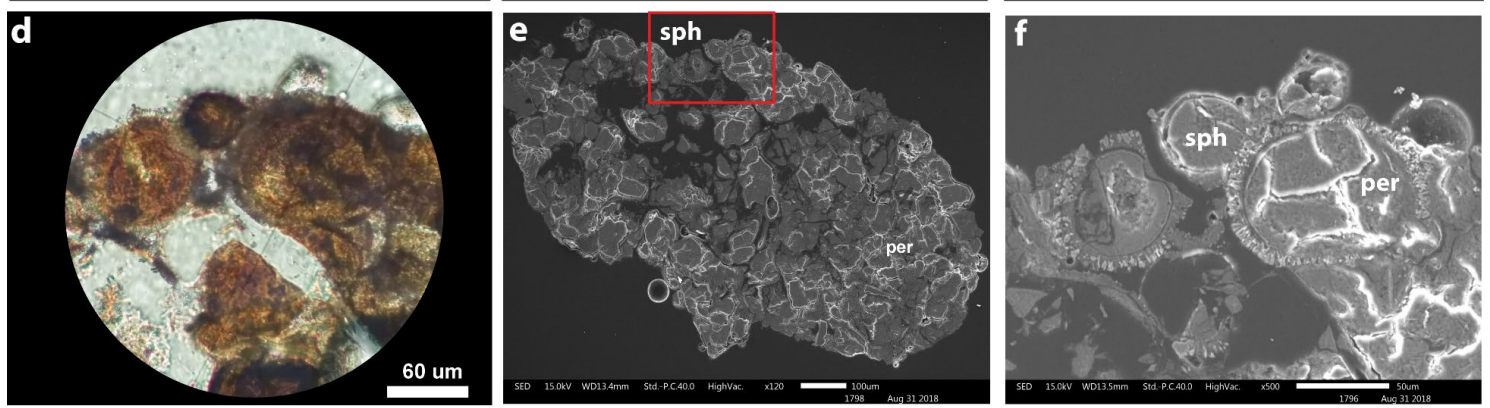

607 Figure 12: Washed cutting sample (a) from the interval 1130 to $1140 \mathrm{~m}$ showing well-

608 indurated spherules (sph) and vesicles (ves). (b and c) Thin-sections in plain-polarized

609 light and (d), cross-polarized light, and (e and f) SEM. These spherules contain a

610 devitrified (palagonite) inner core, a single concentric outer rim, and an external array

611 of acicular crystals in a radial pattern, typically associated with perlitic cracks (per).

612 Detail of the red circle highlighted in (c) is shown in (d). Detail of the red square in (e)

613 is shown in (f). Pervasive alteration to palagonite is common. 


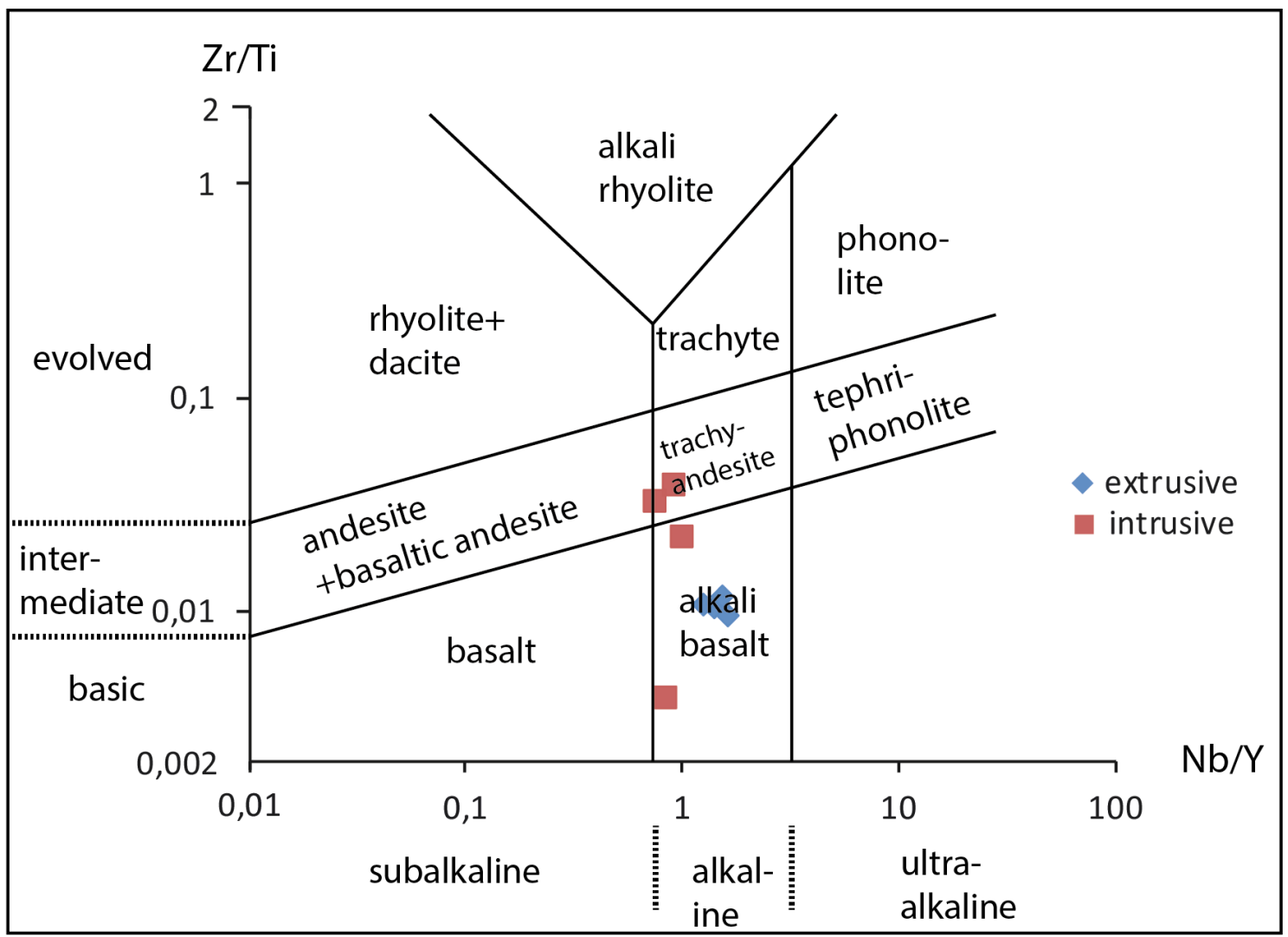

616 Figure 13: $\mathrm{Zr} / \mathrm{Ti}$ versus $\mathrm{Nb} / \mathrm{Y}$ diagram (Pearce 1996 after Winchester and Floyd 1977),

617 used to compare the composition of the igneous rocks sampled in Resolution-1. Both

618 extrusive and intrusive rocks plot in the alkaline series suggesting a possible co-genetic

619 relationship of these rocks, which is reinforced by analysis of seismic reflection lines in 620 the vicinity of the well (Figure 14 and 15). 


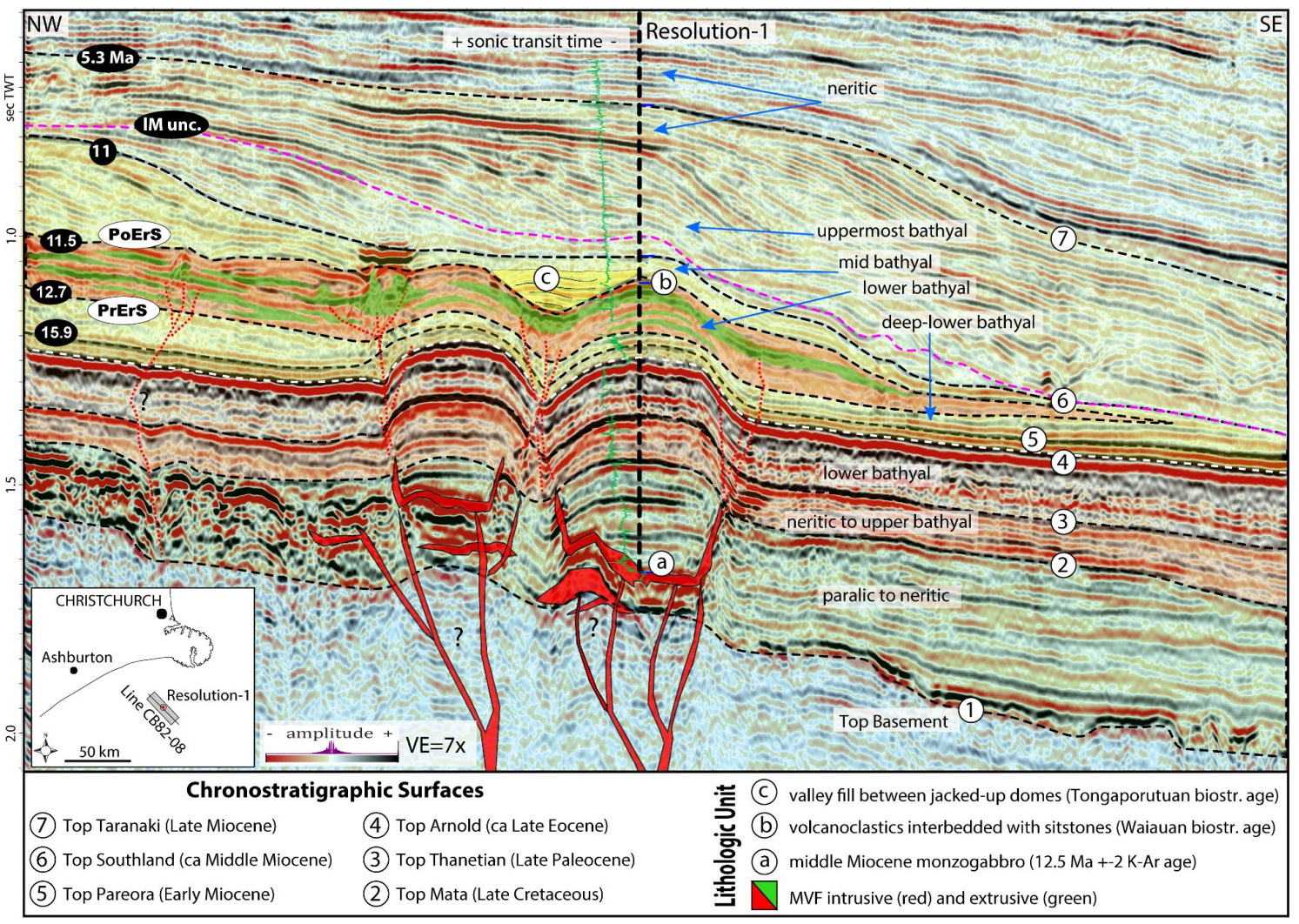

622 Figure 14: Interpreted 2D dip seismic section at the location of Resolution-1 (thick

623 dashed line). Saucer-shaped sills (a) were intruded into Cretaceous sedimentary strata

624 during the Miocene (12.5 \pm 2 Ma K-Ar date). The syn-eruptive interval (between PrErS

625 and PoErS) is defined by the occurrence of volcaniclastic rocks (b) interbedded with the

626 Tokama Siltstone of Waiauan age (ca 12.7 to $11 \mathrm{Ma}$ ). The emplacement of these

627 intrusions caused doming of the overlying strata, consequentially changing the paleo-

628 sea floor topography and promoting deposition of channelized systems (c) next to the

629 dome structures during the late Waiauan (11.5 to $11 \mathrm{Ma})$. 


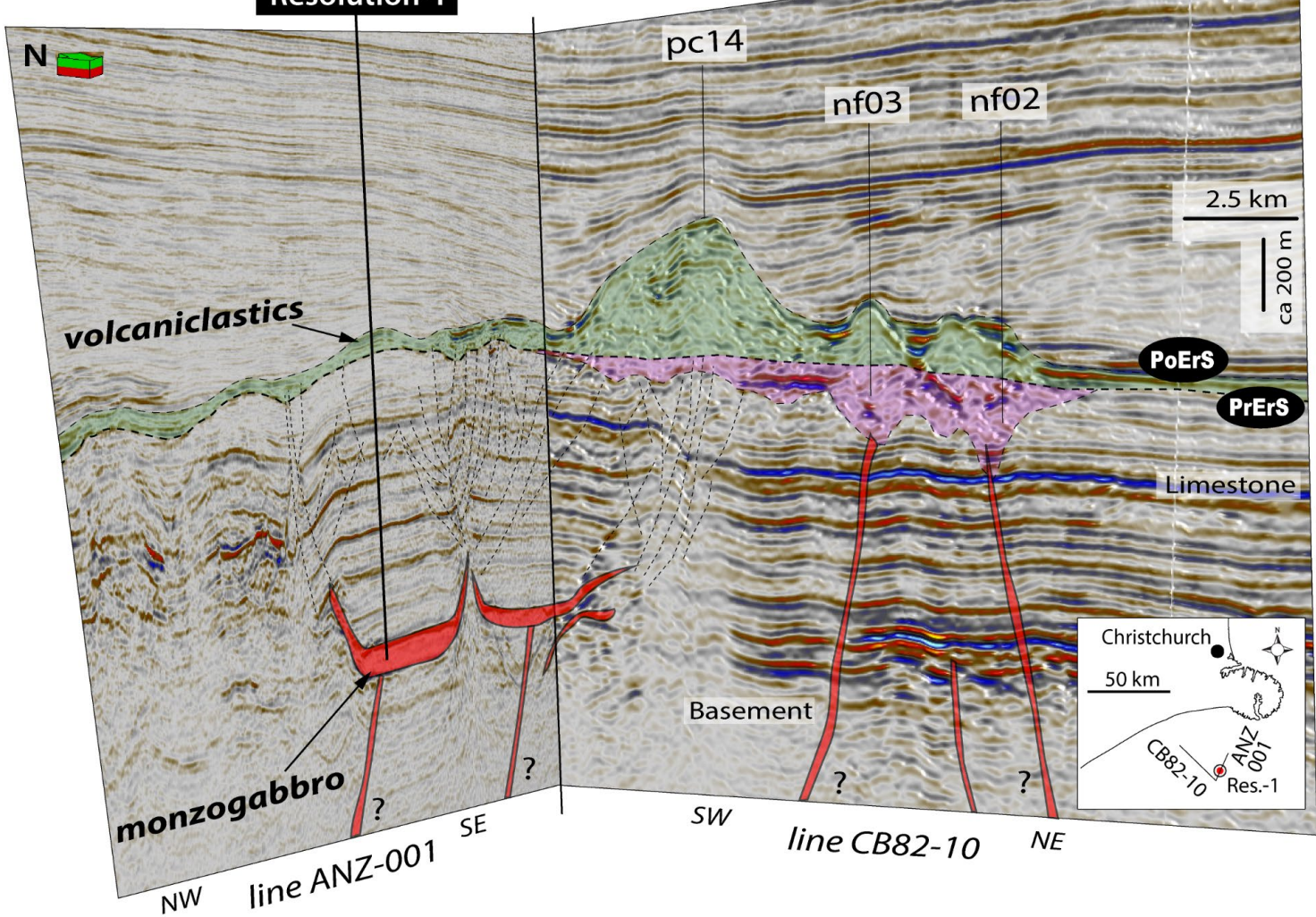

631 Figure 15: Interpreted 2D composite section at the location of Resolution-1 showing the

632 seismic expression of the shallow plumbing system and the morphology of some of the

633 volcanoes in the MVF. Note the array of faults at the tips of the saucer-shaped

634 intrusions, which possibly aided pathways for magma and hydrothermal fluids migrate

635 up-sequence. Note that the extension of these faults connects the saucer-shaped

636 intrusions (bottom) with the root of the volcano pc14 (top), suggesting a feeding system

637 for eruptions onto the Miocene paleo-sea bed. The zone highlighted in purple below the

638 volcanoes pc14, nf02 and nf03 is interpreted to correspond with craters excavated into

639 the pre-eruptive surface.

640

641

642

643

644

645 


\begin{tabular}{|ccccccccccccccccccc} 
& $\mathrm{SiO}_{2}$ & $\mathrm{Al}_{2} \mathrm{O}_{3}$ & $\mathbf{M g O}$ & $\mathrm{Fe}_{2} \mathrm{O}_{3}$ & $\mathrm{CaO}$ & $\mathrm{K}_{2} \mathrm{O}_{5}$ & $\mathrm{P}_{2} \mathrm{O}_{5}$ & $\mathrm{TiO}_{2}$ & $\mathrm{MnO}$ & $\mathrm{Total}$ & $\mathrm{Ti}$ & $\mathbf{Y}$ & $\mathrm{Zr}$ & $\mathrm{Nb}$ & $\mathrm{Nb} / \mathrm{Y}$ & $\mathrm{Zr} / \mathrm{Ti}$ \\
Int_s1 & 45,50 & 17,38 & 3,74 & 12,10 & 4,66 & 1,64 & 0,45 & 2,33 & 0,13 & 87,93 & 13942 & 22,4 & 304,6 & 23,3 & 1,040 & 0,022 \\
Int_s2 & 48,44 & 17,98 & 4,82 & 11,97 & 6,21 & 1,76 & 0,80 & 1,39 & 0,13 & 93,49 & 8358 & 24,4 & 323 & 23 & 0,943 & 0,039 \\
Int_s3 & 55,86 & 20,09 & 4,37 & 7,95 & 8,38 & 1,45 & 0,14 & 1,09 & 0,11 & 99,44 & 6562 & 22,4 & 210,4 & 17,4 & 0,777 & 0,032 \\
Int_s4 & 47,65 & 15,27 & 6,68 & 8,66 & 12,90 & 0,34 & 0,14 & 4,82 & 0,12 & 96,58 & 28878 & 14,9 & 111,6 & 12,8 & 0,859 & 0,004 \\
Ext_s1 & 54,93 & 16,59 & 5,47 & 20,93 & 10,35 & 2,85 & 0,53 & 4,64 & 0,29 & 116,59 & 27824 & 43,6 & 297,8 & 61,4 & 1,408 & 0,011 \\
Ext_s2 & 48,03 & 13,96 & 5,74 & 22,53 & 13,49 & 1,76 & 0,56 & 4,77 & 0,39 & 111,23 & 28587 & 38,1 & 279,8 & 61,3 & 1,609 & 0,010 \\
Ext_s3 & 45,07 & 14,74 & 4,97 & 19,16 & 13,42 & 2,13 & 0,71 & 3,78 & 0,36 & 104,33 & 22655 & 44,8 & 245,2 & 56,2 & 1,254 & 0,011 \\
Ext_s4 & 40,81 & 13,54 & 4,07 & 15,62 & 11,89 & 1,80 & 0,49 & 3,10 & 0,29 & 91,61 & 18595 & 31,9 & 221,4 & 49,1 & 1,539 & 0,012
\end{tabular}

647 Appendix 1: XRF results from Rock Association I (intrusive) and Rock Association V 648 (extrusive) of Resolution-1. Sn correspond to the number of shots given in each sample. 649 Major elements are presented in weight percent (wt $\%$ ), while incompatible elements are 650 in parts per million (ppm).
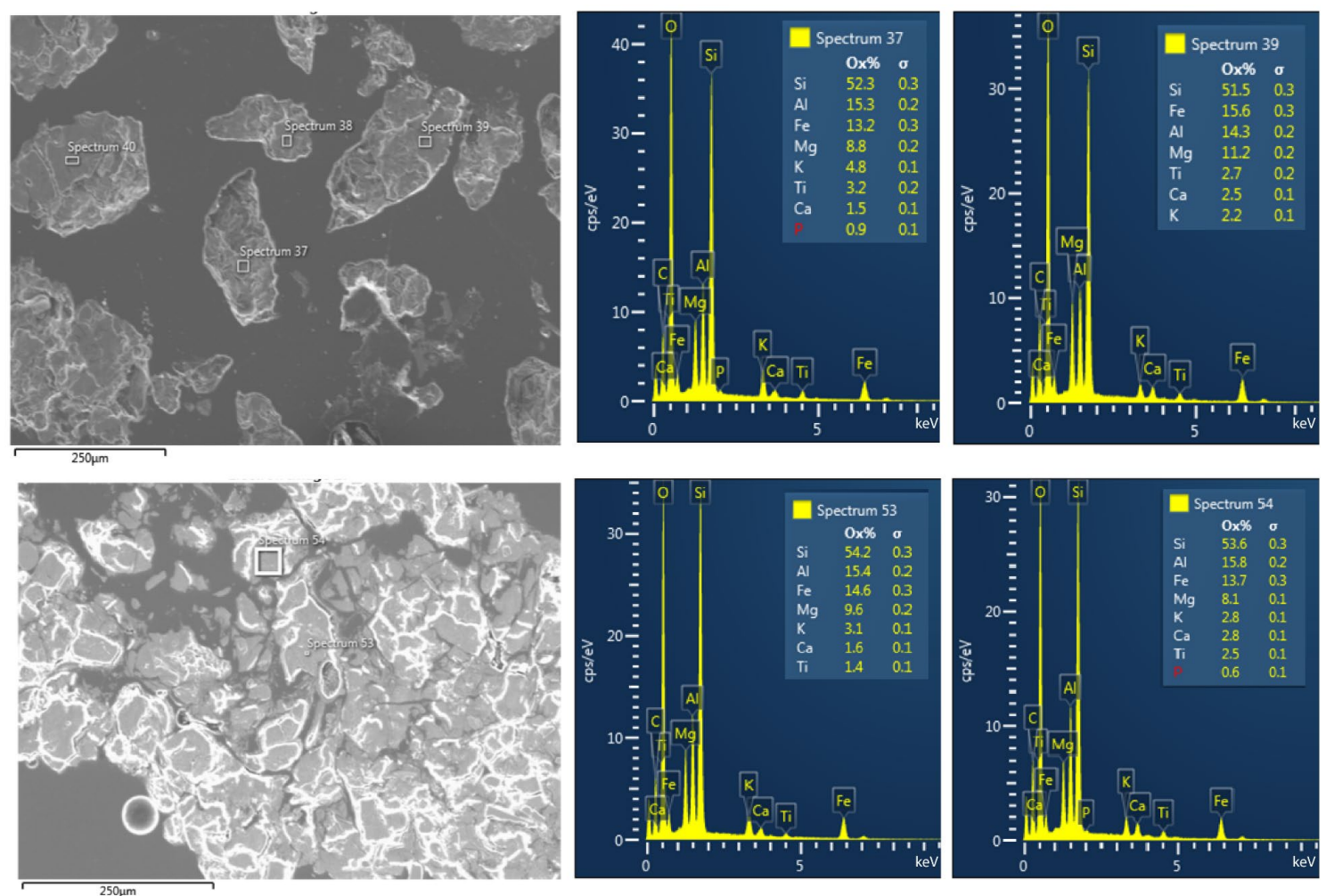

651

652

Appendix 2: Results from EDS analysis of volcanic glass from Rock Association V. 
656 We would like to thank IHS Markit and Schlumberger for providing academic licence

657 to use the Kingdom and Petrel software, and the NZPM for providing the dataset for

658 this study. Thanks to Jane Newman for the petrographic insights, to Simon Holford and

659 Sverre Planke for their excellent reviews of the manuscript, and to Judy Fierstein for

660 helping to improve this paper.

\section{References}

662 Aarnes I, Planke S, Trulsvik M, Svensen H (2015) Contact metamorphism and

663

664

665 thermogenic gas generation in the Vøring and Møre basins, offshore Norway,

664 during the Paleocene-Eocene thermal maximum. J Geol Soc 172: 588-598

666

667

668

669

670

671

672

673

Barrier, A., 2019. Tectonics, Sedimentation and Magmatism of the Canterbury Basin, New Zealand. Ph.D. Thesis, Canterbury University, New Zealand.

674

Barrier A, Nicol A, Bischoff AP (2017) Volcanism Occurrences in the Canterbury

675

676

677

678

679

680 Basin, New Zealand and Implication for Petroleum Exploration. In AAPG GTW

Arnórsson S, Thórhallsson S, Stefánsson A (2015) Utilization of Geothermal Resources, in The Encyclopedia of Volcanoes. https://doi.org/10.1016/B978-0-12-3859389.00071-7 Influence of Volcanism and Associated Magmatic Processes on Petroleum Systems. Conference, Oamaru New Zealand.

Best MG, Christiansen EH (1997) Origin of broken phenocrysts in ash-flow tuffs. Geol Soc Am Bull.

682 https://doi.org/10.1130/00167606(1997)109<0063:OOBPIA>2.3.CO;2

Bischoff AP, Nicol A, Barrier A, Beggs M (2016) The Stratigraphic Record of Volcanism - Examples from New Zealand Sedimentary Basins. In 2016 Geoscience Society of New Zealand Conference, Wanaka, Abstract. 
684 Bischoff AP, Nicol A, Beggs M (2017) Stratigraphy of architectural elements in a

685

686

687

688

689

690

691

692

693

694

695

696

697

698

699

700

701

702

703

704

705

706

707

708

709

710

711

712

713

714

715

716 buried volcanic system and implications for hydrocarbon exploration: Interpretation. https://doi.org/10.1190/INT-2016-0201.1

Bischoff AP (2019) Architectural Elements of Buried Volcanic Systems and Their Impact on Geoenergy Resources. Ph.D. Thesis, Canterbury University, New Zealand. Pre-print, pp 226. 10.13140/RG.2.2.21440.58886

Bischoff AP, Nicol A, Barrier A, Wang H (2019a) Seismic Morphological and Paleogeographic Reconstruction of Buried Monogenetic Volcanic Field. Online pre-print in EarthArXiv. Submitted to the Bulletin of Volcanology. 10.31223/osf.io/3yrcu

Bischoff AP, Nicol A, Cole J, Gravley D (2019b) Stratigraphy of Architectural Elements of a Buried Monogenetic Volcanic System and Implications for Geoenergy Exploration. Online pre-print in EarthArXiv. Submitted to the Open Geosci. 10.31223/osf.io/h9zuq

Blanke SJ (2010) "Saucer Sills" of the Offshore Canterbury Basin: GNS Publication. https://doi.org:10.1177/0094306114545742f

Browne GH (1983) A new interpretation of brecciation in the sandpit tuff, harper hills, Canterbury. New Zeal J Geol Geophys. https://doi.org/10.1080/00288306.1983.10422258

Carlson JR, Grant-Mackie JA, Rodgers KA (1980) Stratigraphy and sedimentology of the coalgate area, Canterbury, New Zealand: New Zeal J Geol Geop. https://doi.org/10.1080/00288306.1980.10424205

Cas RA, Wright FJV (1993) Volcanic Successions: Modern and Ancient - A Geological Approach to Processes, Products and Successions. Chapman and Hall, UK. https://doi.org:10.1007/978-0-412-44640-5

Cas RA, Giordano FG (2014) Submarine volcanism: A review of the constraints, processes and products, and relevance to the Cabo de Gata volcanic succession. https://doi.org:10.3301/IJG.2014.46

Catuneanu O (2006) Principles of Sequence Stratigraphy. Changes, 375. https://doi.org:10.5860/CHOICE.44-4462

Coombs DS, White AJR, Hamilton D, Couper RA (1960) Age relations of the Dunedin volcanic complex and some paleogeographic implications-Part II: New Zeal J Geol Geop. https://doi.org:10.1080/00288306.1960.10420145 
717 Coombs DS, Cas RA, Kawachi Y, Landis CA, McDonough WF, Reay A (1986)

718

719

720

721

722

723

724

725

726

727

728

729

730

731

732

733

734

735

736

737

738

739

740

741

742

743

744

745

746

747

748 Cenozoic volcanism in north, east and central Otago. In: Smith IEM (ed) Late Cenozoic Volcanism in New Zealand. R Soc New Zeal Bull 23: 278-312

Delmelle P, Maters E, Oppenheimer C (2015) Volcanic Influences on the Carbon, Sulfur, and Halogen Biogeochemical Cycles. In: Sigurdsson H, Houghton B, McNutt S, Rymer H, Stix J (eds) Encyclopedia of Volcanoes. Academic Press, New York. https://doi.org/10.1016/B978-0-12-385938-9.00050-X

Eady AE (1995) The Petrology and Geochemistry of the Acheron Intrusion. MSc Thesis, Canterbury University pp 183. http://hdl.handle.net/10092/6783

Field BD, Browne GH, Davy BW, Herzer RH, Hoskins RH, Raine JI, Wilson GJ, Sewell RJ, Smale D, Watters WA (1989) Cretaceous and Cenozoic sedimentary basins and geological evolution of the Canterbury region, South Island, New Zealand. Lower Hutt: New Zealand Geological Survey. New Zealand Geological Survey Basin Studies 2: 94.

Finn CA, Müller RD, Panter KS (2005) A Cenozoic diffuse alkaline magmatic province (DAMP) in the southwest Pacific without rift or plume origin. Geochem Geophys Geosy. https://doi.org/10.1029/2004GC000723

Forsyth PJ, Barrell D.J.A, Jongens R (2008) Geology of the Christchurch area. Institute of Geological and Nuclear Sciences 1:250,000 Geological Map 16. Lower Hutt, GNS Science. $67 \mathrm{p} 1$ sheet.

Giba M, Walsh JJ, Nicol A, Mouslopoulou V, Seebeck H (2013) Investigation of the Spatio-Temporal Relationship between Normal Faulting and Arc Volcanism on Million-Year Time Scales. J Geol Soc 170: 951-962. https://doi.org/10.1144/jgs2012-121

Graettinger AH, Valentine GA, Sonder I (2016) Recycling in Debris-Filled Volcanic Vents. Geology 44: 811. https://doi.org/10.1130/G38081.1

Hawkes PW, Mound DD (1984) BP Shell Todd (Canterbury) Services Limited, Clipper1 Geological Completion Report PR1036.

Holford SP, Schofield N, MacDonald JD, Duddy IR, Green PF (2012) Seismic Analysis of Igneous Systems in Sedimentary Basins and Their Impacts on Hydrocarbon Prospectivity: Examples from the Southern Australian Margin. APPEA Journal, 52: $229-252$. 
Hunt D, Tucker ME (1992) Stranded parasequences and the forced regressive wedge systems tract: deposition during base-level fall: Sediment Geol 81: 1-9. https://doi.org/10.1016/0037-0738(92)90052-S

Huafeng T, Phiri C, Youfeng G, Yulong H, Weihua, B (2015) Types and Characteristics of Volcanostratigraphic Boundaries and Their Oil-Gas Reservoir Significance. Acta Geologica Sinica - English Edition, 89: 163-174. https://doi.org/10.1111/1755-6724.12402

Iacono-Marziano G, Morizet Y, Le Trong E, Gaillard F (2013) New experimental data and semi-empirical parameterization of $\mathrm{H} 2 \mathrm{O}-\mathrm{CO} 2$ solubility in mafic melts. Geochimica Et Cosmochimica Acta 97: 145-157

Infante-Paez L, Marfurt KJ (2017) Seismic expression and geomorphology of igneous bodies: A Taranaki Basin, New Zealand, case study: Interpretation, 5, no. 3, p. SK121-SK140, https://doi.org/10.1190/INT-2016-0244.1

Jerram DA, Single RT, Hobbs RW, Nelson CE (2009) Understanding the offshore flood basalt sequence using onshore volcanic facies analogues: An example from the Faroe-Shetland basin. Geol Mag. https://doi.org/10.1017/S0016756809005974

Kamp PJJ, Green PF, Tippett JM (1992) Tectonic architecture of the mountain frontforeland basin transition, South Island, New Zealand, assessed by fission track analysis. Tectonics. https://doi.org/10.1029/91TC02362

Kereszturi G, Németh C (2013) Monogenetic Basaltic Volcanoes: Genetic Classification, Growth, Geomorphology and Degradation: Updates in Volcanology - New Advances in Understanding Volcanic Systems, https://doi.org/10.5772/51387

Lever H (2007) Review of unconformities in the late Eocene to early Miocene successions of the South Island, New Zealand: Ages, correlations, and causes: New Zeal J Geol Geophys 50: 245-261

Lu H, Fulthorpe CS, Mann P, Kominz MA (2005) Miocene-Recent tectonic and climatic controls on sediment supply and sequence stratigraphy: Canterbury basin, New Zealand: Basin Res 17: 311-328. https://doi.org/10.5772/5138710.1111/j.1365-2117.2005.00266.x Lorenz V (1985) Maars and diatremes of phreatomagmatic origin, a review. Transactions of the Geological Society of South Africa 88: 459-470. 
Marfurt K (2018) Seismic Attributes as the Framework for Data Integration Throughout the Oilfield Life Cycle: Society of Exploration Geophysicists pp 508. https://doi.org/10.1190/1.9781560803522

McPhie J, Doyle M, Allen R (1993) Volcanic textures - a guide to the interpretation of textures in volcanic rocks. Centre for Ore Deposit and Exploration Studies, University of Tasmania.

McLean CE, Schofield N, Brown DJ, Jolley DW, Reid A (2017) 3D seismic imaging of the shallow plumbing system beneath the Ben Nevis Monogenetic Volcanic Field: Faroe-Shetland Basin: J Geol Soc. https://doi.org/10.1144/jgs2016-118

Magee C, Murray H, Christopher JAL, Stephen JM (2019) Burial-Related Compaction Modifies Intrusion-Induced Forced Folds: Implications for Reconciling Roof Uplift Mechanisms Using Seismic Reflection Data. Front Earth Sci. doi:10.3389/feart.2019.00037

Milne AD (1975) Well completion report Resolution, for BP, Shell, Todd Canterbury Service Limited. New Zealand Geological Survey Open-file Petroleum Report No. 648.

Mortimer N (2004) New Zealand's Geological Foundations: Gondwana Research, v. 7, no. 1, p. 261-272.

Pearce TH (1993) Analcime phenocrysts in igneous rocks: Primary or secondary? Discussion. Am Mineral 78: 225-229.

Pearce JA (1996) A users guide to basalt discrimination diagrams. In: Wyman DA (eds). Trace Element Geochemistry of Volcanic Rocks: Applications for Massive Sulphide Exploration. Short Course Notes 12. St. John's, Canada: Geological Association of Canada, pp 79-113

Peretyazhko IS (2010) Genesis of mineralized cavities (Miaroles) in granitic pegmatites and granites. Petrol. https://doi.org/10.1134/S0869591110020062

Planke S, Alvestad E, Eldholm O (1999) Seismic Characteristics of Basaltic Extrusive and Intrusive Rocks. The Leading Edge 18: 342. https://doi.org/10.1190/1.1438289

Planke S, Symonds PA, Alvestad E, Skogseid J (2000) Seismic Volcanostratigraphy of Large-Volume Basaltic Extrusive Complexes on Rifted Margins. J Geophys Res 105 (B8): 19335. https://doi.org/10.1029/1999JB900005

Planke S, Millett JM, Maharjan D, Jerram DA, Abdelmalak MM, Groth A, Hoffmann J, Berndt C, Myklebust R (2017) Igneous seismic geomorphology of buried lava 

fields and coastal escarpments on the Vøring volcanic rifted margin: Interpretation. https://doi.org/10.1190/INT-2016-0164.1

Reynolds P, Schofield N, Brown RJ, Holford SP (2016) The architecture of submarine monogenetic volcanoes - insights from 3D seismic data: Basin Res 30: 437-451. https://doi.org/10.1111/bre.12230

Robertson J, Ripley EM, Barnes SJ, Li C (2015) Sulfur liberation from country rocks and incorporation in mafic magmas: Econ Geol. https://doi.org/10.2113/econgeo.110.4.1111

Schofield N, Jerram DA, Holford S, Stuart A, Niall M, Hartley A, Howell J, David M, Green P, Hutton D, Stevenson C (2016) Sills in sedimentary basin and petroleum systems: In Németh K (ed) The Series Advances in Volcanology, pp $1-22$

Sewell RJ (1988) Late Miocene volcanic stratigraphy of central Banks Peninsula, Canterbury, New Zealand pp. 41-64. https://doi.org/10.1080/00288306.1988.10417809

Single RT, Jerram DA (2004) The 3-D facies architecture of flood basalt provinces and their internal heterogeneity: examples from the Palaeogene Skye Lava Field. J Geol Soc 161: 911-926

Smith KL, Milnes AR, Eggleton RA (1987) Weathering of basalt: formation of iddingsite. Clays Clay Miner 35: 418-428

Schiøler P, Raine JI, Griffin A, Hollis CJ, Kulhanek DK, Morgans HEG, Roncaglia L, Strong CP, Uruski C (2011) Revised biostratigraphy and well correlation, Canterbury Basin, New Zealand. GNS Science Consultancy Report 2011/12. $142 \mathrm{p}$.

Stroncik NA, Schmincke HU (2002) Palagonite - A review: Int J Earth Sci. https://doi.org/10.1007/s00531-001-0238-7

Strogen DP, Seebeck H, Nicol A, King PR (2017) Two-phase Cretaceous-Paleocene rifting in the Taranaki Basin region, New Zealand; implications for Gondwana break-up: Journal of the Geological Society, https://doi.org/10.1144/jgs2016-160

Suggate RP, Stevens GR, Te Punga MT (1978) The geology of New Zealand. Govt Printer, Wellington.

Svensen HH, Planke S, Neumann ER, Aarnes I, Marsh JS, Polteau S, Harstad C, Chevallier L (2018) Sub-volcanic intrusions and the link to global climatic and environmental changes. In: Breitkreuz C., Rocchi S. (eds) Physical Geology of 

https://doi.org/10.1007/978-3-319-14084-1_10.

851 Svensen HH, Planke S, Malthe-Sørenssen A, Jamtveit B, Myklebust R, Eidem T, Rey S S (2004) Release of methane from a volcanic basin as a mechanism for initial Eocene global warming. Nature, 429, 542-545.

854 Timm C, Hoernle K, Werner R, Hauff F, van den Bogaard P, White J, Mortimer N, 855 Garbe-Schönberg D (2010) Temporal and geochemical evolution of the Cenozoic intraplate volcanism of Zealandia. https://doi.org/10.1016/j.earscirev.2009.10.002

858 Walker F (1957) Ophitic Texture and Basaltic Crystallization. J Geol 65: 1-14. http://www.jstor.org/stable/30064199.

860 Walker GPL, Croasdale R (1971) Characteristics of some basaltic pyroclastics: Bull Volcanol. https://doi.org/10.1007/BF02596957

862 White JDL (2000) Subaqueous eruption-fed density currents and their deposits: Precambrian Res 101: 87-109. https://doi.org/10.1016/S0301-9268(99)00096-0

864 White JDL, Ross PS (2011) Maar-diatreme volcanoes: A review. https://doi.org/10.1016/j.jvolgeores.2011.01.010

866 White JDL, Valentine GA (2016) Magmatic versus phreatomagmatic fragmentation: Absence of evidence is not evidence of absence. Geosphere 12: 1478-1488. https://doi.org/10.1130/GES01337.1

869 Zimanowski B, Büttner R, Lorenz V, Häfele HG (1997) Fragmentation of basaltic melt in the course of explosive volcanism. J Geophys Res Sol Earth. doi:10.1029/96JB02935 